\title{
Thermal History of UHT Metamorphism in the Napier Complex, East Antarctica: Insights from Zircon, Monazite, and Garnet Ages
}

\author{
Satoko Suzuki, ${ }^{1}$ Makoto Arima, ${ }^{2}$ Ian S. Williams, ${ }^{3}$ Kazuyuki Shiraishi, ${ }^{4}$ \\ and Hiroo Kagami ${ }^{5}$
}

\author{
Nagoya University Center for Chronological Research, Nagoya 464-8602, Japan \\ (e-mail: satoko@nendai.nagoya-u.ac.jp)
}

\begin{abstract}
A B S T R A C T
High-grade gneisses from Mt. Riiser-Larsen, East Antarctica, have been dated by whole-rock-mineral Sm-Nd and SHRIMP zircon and monazite U-Pb to help define the thermal history of ultrahigh temperature (UHT) metamorphism in the Napier Complex. Both the monazite and youngest zircon yield a range of apparent ages $(\sim 2.51-2.47 \mathrm{Ga})$, consistent with crystallization during an extended period of metamorphism. Some zircon also preserves an isotopic record of earlier events, placing an upper limit of a few million years on the duration of peak metamorphic conditions. The similarity of the monazite and zircon U-Pb ages implies rapid initial postpeak cooling to below the blocking temperature of these minerals $\left(\sim 900^{\circ} \mathrm{C}\right)$. Consistently lower Sm-Nd whole-rock-mineral isochron ages $(\sim 2.38 \mathrm{Ga})$ indicate that cooling slowed before the temperature reached $\sim 650^{\circ} \mathrm{C}$. The history of the UHT metamorphism is interpreted to be (1) protracted high-temperature $\left(\geq 800^{\circ} \mathrm{C}\right.$ ) conditions $\sim 2.51-2.47 \mathrm{Ga}$, (2) peak conditions (up to $1100^{\circ} \mathrm{C}$ ) for at most a few million years, (3) rapid cooling $\left(10^{\circ}-60^{\circ} \mathrm{C} / \mathrm{m}\right.$.yr.) immediately after peak metamorphism, and (4) very slow cooling $\left(\leq 4^{\circ} \mathrm{C} / \mathrm{m}\right.$.yr.) at midcrustal levels $(\sim 30-\mathrm{km}$ depth) to a steady state geotherm by $2.38 \mathrm{Ga}$.
\end{abstract}

Online enhancements: tables.

\section{Introduction}

The Archean Napier Complex, East Antarctica (fig. $1)$, has attracted considerable attention from petrologists and geochemists since Dallwitz (1968) first reported the occurrence of an extremely high temperature assemblage: sapphirine + quartz. Interest increased even further after ages of $\sim 4.0 \mathrm{Ga}$ were first reported in the Casey Bay area by Sobotovich et al. (1976). Very early Archean ages of $\sim 3.8$ to $\sim 3.9$ Ga were subsequently confirmed by SHRIMP zircon U-Pb dating (Compston and Wil2005.

Manuscript received January 6, 2004; accepted August 23,

${ }^{1}$ Author for correspondence.

${ }^{2}$ Geological Institute, Graduate School of Environment and Information Sciences, Yokohama National University, Yokohama 240-8501, Japan.

${ }^{3}$ Research School of Earth Sciences, Australian National University, Canberra, Australian Capital Territory 0200, Australia.

${ }^{4}$ National Institute of Polar Research, Itabashi, Tokyo 1738515, Japan.

${ }^{5}$ Graduate School of Science and Technology, Niigata University, Niigata 950-2181, Japan. liams 1982; Williams et al. 1984; Black et al. 1986b; Harley and Black 1997; Williams 1998; Kelly and Harley 2005; fig. 2).

The Napier Complex consists predominantly of massive pyroxene-quartz-feldspar orthogneiss with subordinate amounts of mafic granulite and layered garnet-quartz-feldspar orthogneiss with siliceous, aluminous, or ferruginous paragneiss (Sheraton et al. 1980). The paragneisses locally contain sapphirine + quartz (Dallwitz 1968; Ellis 1980; Grew 1980; Motoyoshi and Hensen 1989; Harley and Hensen 1990), osumilite (Ellis 1980; Grew 1982), inverted pigeonite (Sandiford and Powell 1986; Harley 1987), and/or orthopyroxene + sillimanite + quartz (Harley 1985; Sheraton et al. 1987). These assemblages are diagnostic of ultrahigh-temperature (UHT) crustal metamorphism $\left(>900^{\circ} \mathrm{C}\right)$ at $7-11$ kbar (Harley 1998). Recent petrological studies at Amundsen Bay, in the western part of the Napier Complex, indicate that peak metamorphic temperatures in that area exceeded $1100^{\circ} \mathrm{C}$ (e.g., Harley and Motoyoshi 2000; Hokada

[The Journal of Geology, 2006, volume 114, p. 65-84] @ 2006 by The University of Chicago. All rights reserved. 0022-1376/2006/11401-0004\$15.00 


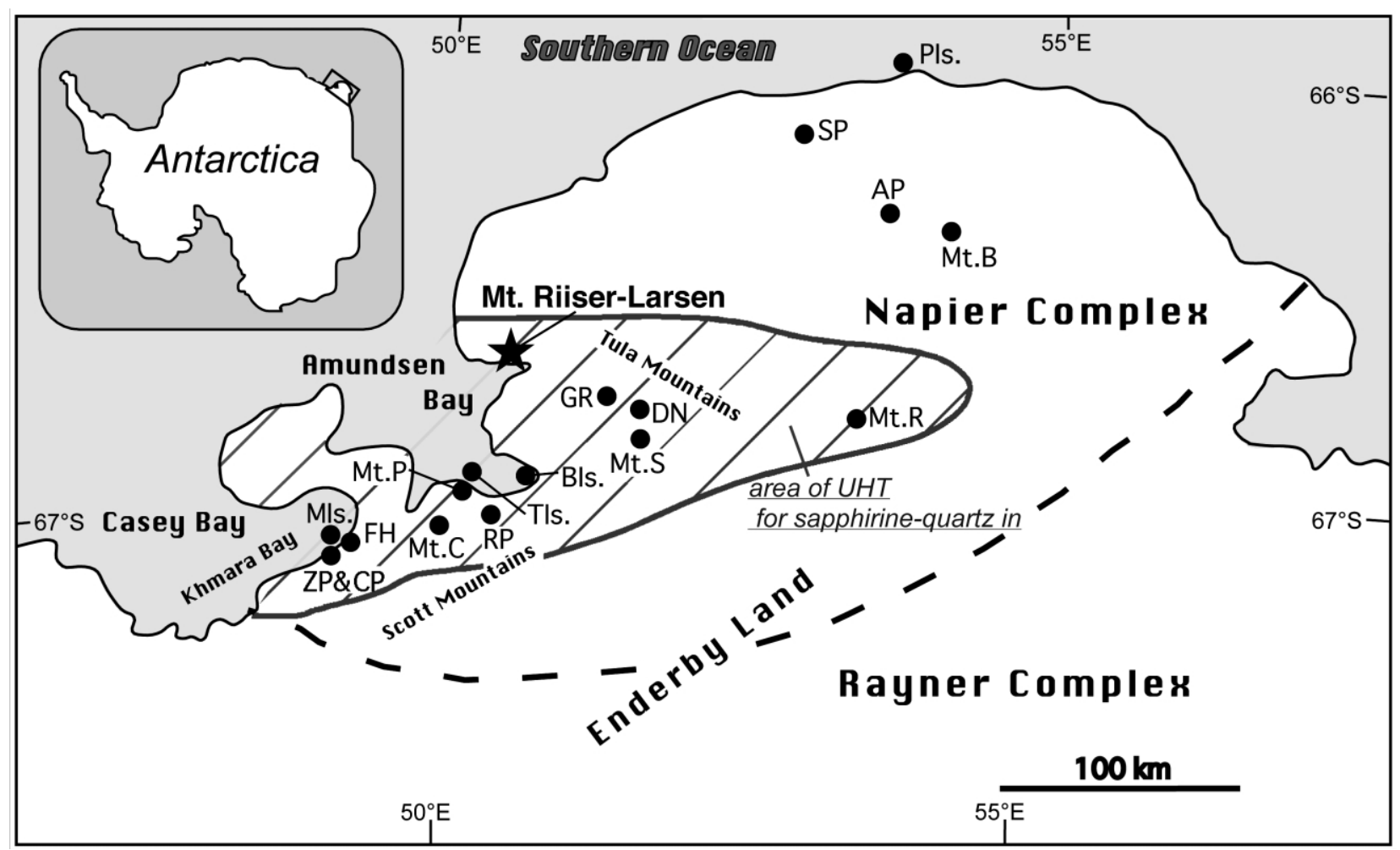

Figure 1. Index map of the Napier Complex, Enderby Land, East Antarctica, showing the location of Mt. RiiserLarsen. The zone of ultrahigh temperature metamorphism is that outlined by Harley and Hensen (1990). $A P=$ Armstrong Peak, $B I s=$ Beaver Island, $D N=$ Dallwitz Nunatack, $F H=$ Fyfe Hills, $G R=$ Gage Ridge, $M I s=$ McIntyre Island, $M t . B=$ Mt. Bride, $M t . C=$ Mt. Cronus, $M t . P=M t$. Pardoe, $M t . R=M t$. Renouard, $M t . S=M t$. Sones, $P I s=$ Proclamation Island, $R P=$ References Peak, $S P=$ Simmers Peaks, $T I s=$ Tonagh Island, $Z P \& C P=Z$ ircon and Christmas Points.

2001). Petrographic evidence from various parts of the complex has been used to infer that postpeak cooling was near isobaric (e.g., Hollis and Harley 2002).

The thermal history of the Napier region is complicated, so the age of peak UHT metamorphism in the Napier Complex has been a subject of considerable debate. SHRIMP zircon U-Pb dating has been interpreted as supporting each of three contrasting views: first, that UHT metamorphism occurred at $2.84 \mathrm{Ga}$ (Harley and Black 1997); second, that it occurred at $\sim 2.59-2.55$ Ga (Harley et al. 2001; Crowe et al. 2002; Kelly and Harley 2005); and third, that it occurred later, at $\sim 2.50-2.45 \mathrm{Ga}$ (Grew 1998; Carson et al. 2002; Hokada et al. 2003; Hokada and Harley 2004). Furthermore, Sheraton and Black (1981) reported Rb-Sr whole-rock isochron ages of $\sim 2.5$ to $\sim 2.3 \mathrm{Ga}$ for tholeiite intrusion during the waning stages of granulite facies metamorphism throughout the complex. The difficulty in dating both peak metamorphism and the pro- grade and retrograde $P T$ paths has left the $P T-t$ evolution of UHT metamorphism in the Napier Complex poorly constrained. In this article, we report the results of a geochronological study of a granitic gneiss and associated psammitic gneiss and mafic granulite from Mt. Riiser-Larsen in the Amundsen Bay area. SHRIMP U-Pb ages of zircon and monazite from the granitic gneiss and Sm-Nd mineral isochron ages from the gneiss and associated rocks provide new insights into the evolution and cooling history of UHT metamorphism in the Napier Complex.

\section{Geology of Mt. Riiser-Larsen}

Mount Riiser-Larsen is located in northeast Amundsen Bay, western Napier Complex (fig. 1). The area has been divided into three main lithological units: the Massive Gneiss Series, the Layered Gneiss Series, and between them, the Transitional Gneiss Series (fig. 3; Ishizuka et al. 1998). 

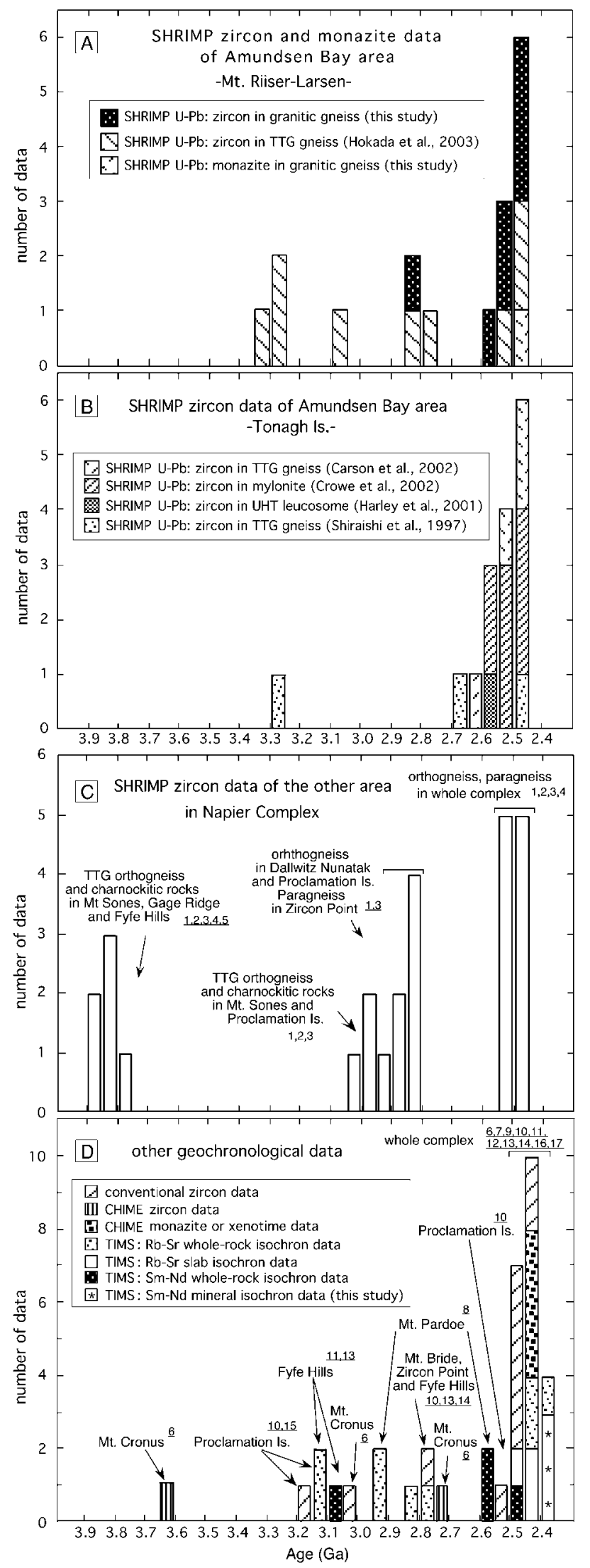

The first consists predominantly of orthogneiss of Archean tonalite-trondhjemite-granodiorite (TTG) affinity, the second of layered paragneisses and orthogneisses, and the third of heterogeneous quartzofeldspathic gneisses with minor amounts of metamorphosed mafic to ultramafic rocks, anorthosite, impure quartzite, and paragneiss.

There have been several studies of the PT conditions at Mt. Riiser-Larsen. Using orthopyroxenegarnet and plagioclase-garnet-sillimanite-quartz geobarometers, Motoyoshi and Matsueda (1984) estimated the peak PT conditions as $8-10 \mathrm{kbar}$ at $900^{\circ} \mathrm{C}$. More recent estimates based on thermodynamic modeling of coexisting $\mathrm{Al}_{2} \mathrm{O}_{3}$-rich orthopyroxene, sapphirine-quartz (Harley and Motoyoshi 2000), Ca-rich ternary mesoperthitic feldspar (Hokada 2001), and porphyroclastic pyroxene in metamorphosed peridotite (Ishizuka et al. 2002), place the peak metamorphic temperature above $1100^{\circ} \mathrm{C}$. On the basis of exsolved compositions of mesoperthitic feldspars in granulites from Mt. Riiser-Larsen, Hokada (2001) suggested that the final equilibrium temperatures of the ternary feldspars were below $700^{\circ} \mathrm{C}$. Ishizuka et al. (2002) argued that the porphyroclast and neoblastic pyroxenes in the peridotites reflect crystallization under UHT metamorphic conditions and recrystallization by deformation during retrogression, respectively. From the pyroxene compositions, they estimated temperatures $>1100^{\circ} \mathrm{C}$ for the UHT metamorphism and $600^{\circ}-650^{\circ} \mathrm{C}$ for the retrogression. The presence of sapphirine-quartz-orthopyroxene symplectites, which are inferred from texture and bulk

Figure 2. Histograms of geochronological data obtained from the Napier Complex. A, SHRIMP zircon ages reported from Mt. Riiser-Larsen; $B$, SHRIMP zircon ages reported from Tonagh Island; $C$, SHRIMP zircon ages reported from other areas within Napier Complex; $D$, other geochronological data including U-Pb ID-TIMS ages, CHIME ages, Sm-Nd isochron ages, and $\mathrm{Rb}-\mathrm{Sr}$ isochron ages reported from various areas within the Napier Complex. Underlined numbers show references: $1=$ Kelly and Harley 2005, 2 = Williams 1998, $3=$ Harley and Black 1997 and Williams et al. 1984, $4=$ Black et al. $1986 b, 5=$ Compston and Williams 1982, $6=$ Asami et al. 2002, 7 = Grew 1998, $8=$ Tainosho et al. 1998, $9=$ Owada et al. 1994, $10=$ Black et al. 1986a, $11=$ Black et al. 1984, $12=$ McCulloch and Black 1984, 13 = Black et al. 1983b, $14=$ Black et al. $1983 a, 15=$ Sheraton and Black 1983, $16=$ James and Black 1981, $17=$ Sheraton and Black 1981. Model ages and age measurements with uncertainties exceeding \pm 250 m.yr. are not included. 


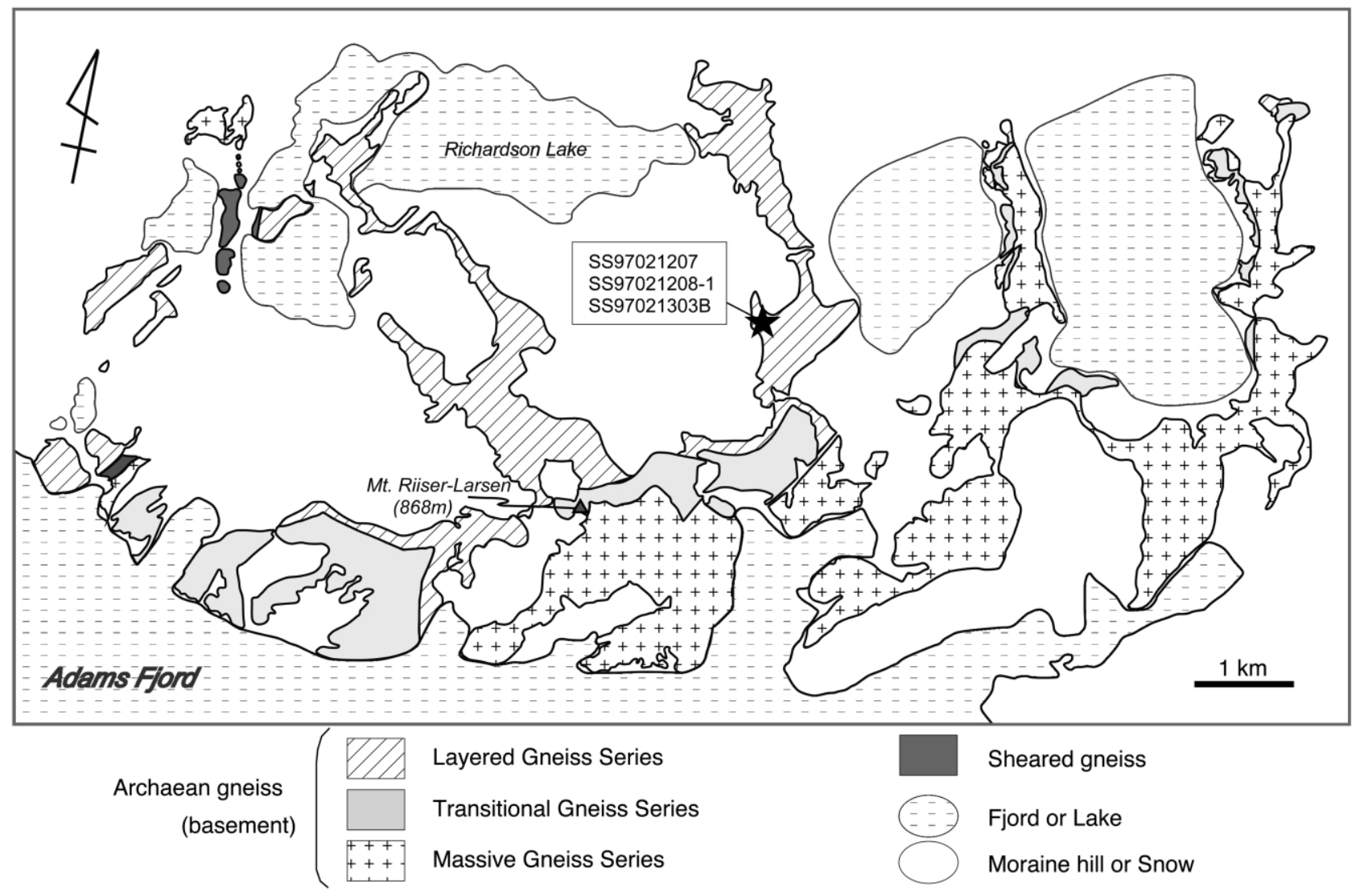

Figure 3. Simplified geologic map of Mt. Riiser-Larsen in Enderby Land, East Antarctica (modified after Ishizuka et al. 1998), showing the location of samples collected for this study.

compositional trends to have replaced cordierite, implies a counterclockwise PT evolution before peak UHT metamorphism (Motoyoshi and Hensen 1989; Hensen and Motoyoshi 1992).

Two phases of folding have been documented in the study area (Ishikawa et al. 2000). The axes of the first phase $\left(\mathrm{F}_{1}\right)$ are aligned NNE-SSW, and fold wavelengths are up to $100 \mathrm{~m}$. The formation of a mineral lineation defining the $F_{1}$ folds is interpreted to have been nearly coeval with the granulite facies metamorphism, but it ceased developing before the peak UHT conditions under which sapphirinequartz and inverted pigeonite crystallized. The second generation of folds $\left(\mathrm{F}_{2}\right)$ formed a broad domal structure. It followed the peak UHT metamorphism and locally disturbed the lithological boundaries and the axial surfaces of the $F_{1}$ folds. The $F_{1}$ and $\mathrm{F}_{2}$ folding might correspond, respectively, to the $\mathrm{D}_{1}-\mathrm{D}_{2}$ deformation, which was probably associated with pervasive $\mathrm{D}_{1}$-lineated gneissosity, and the $\mathrm{D}_{3}$ deformation, characterized by kilometerscale open folds forming regional dome and basin structures (James and Black 1981; Black and James 1983; Sheraton et al. 1987). However, the delicate textures both of sapphirine-quartz symplectite developed in the UHT granulite (during $D_{1}$ ) and of mesoperthitic feldspar indicating exsolution of Carich feldspar following peak UHT conditions have mostly escaped the effects of the later $\mathrm{D}_{2}$ and $\mathrm{D}_{3}$ deformation events.

There have been several geochronological studies of the Mt. Riiser-Larsen area. Hokada et al. (2003) reported clusters of SHRIMP zircon U-Pb ages at $\sim 3.27, \sim 3.07,2.85-2.79$, and $2.52-2.45 \mathrm{Ga}$ from three orthogneisses from the Massive, Transitional, and Layered Gneiss Series. Asami et al. (2002) reported CHIME (chemical Th-U-total Pb isochron method; Suzuki and Adachi 1991) ages of zircon $(\sim 2.44 \mathrm{Ga})$ and monazite $(\sim 2.40, \sim 2.27$, and $\sim 2.03 \mathrm{Ga}$ ) from orthopyroxene quartzofeldspathic granulite and zircon $(2.42 \mathrm{Ga})$ from sapphirine-orthopyroxene-bearing quartzofeldspathic gneiss.

Ages measured by techniques other than U-Pb 
are mostly lower. Suzuki et al. $(2001 b)$ measured an $\mathrm{Sm}-\mathrm{Nd}$ mineral isochron age of $\sim 2.2 \mathrm{Ga}$ on a sapphirine-orthopyroxene-bearing quartzofeldspathic gneiss. Sm-Nd and $\mathrm{Rb}-\mathrm{Sr}$ whole-rock isochron ages of $\sim 2.0$ and $\sim 1.2$ Ga were obtained from vertical mafic dikes that preserve igneous textures (Suzuki et al. 2001a).

\section{Sample Descriptions}

The rocks analyzed for this study were collected from the Layered Gneiss Series (fig. 3). The SHRIMP $\mathrm{U}-\mathrm{Pb}$ method was used to determine the ages of zircon and monazite from a sample of granitic gneiss (SS97021307), and the Sm-Nd mineral isochron method was applied to samples of granitic gneiss (SS97021307), psammitic gneiss (SS97021208-1), and mafic granulite (SS97021303B). Whole-rock compositions are listed in table 1 . All samples were almost free of secondary alteration or the shearing that followed cooling after the late thermal metamorphism.

Granitic gneiss sample SS97021307 was collected from a layer several meters to a few tens of meters thick. The gneiss consists mainly of medium- to coarse-grained garnet, mesoperthite, plagioclase, and quartz. The gneiss is broadly homogeneous with a gneissic granulose texture, but it locally contains thin (<20-mm-thick) layers or lenses of garnetspinel-bearing and sapphirine-bearing gneiss. The garnet (up to $4 \mathrm{~mm}$ diameter) is poikiloblastic, with inclusions of quartz, zircon, monazite, and ilmenite. Two types of garnet have been recognized, one forming relatively inclusion-free grains and the other forming grains containing a high abundance of very fine platy inclusions of monazite and ilmenite $(\leq 0.5$ $\mu \mathrm{m})$. Despite their different textures, both types of garnet have nearly identical compositions $\left(\mathrm{Alm}_{61-64} \mathrm{Pyr}_{31-35} \mathrm{Grs}_{4-5} \mathrm{Sps}_{\leq 0.5}\right)$. The garnet grains commonly are fractured. Fine-grained mica lining the fractures and rimming the garnet grains is probably the product of garnet breakdown during retrogression. Accessory minerals are monazite, zircon, apatite, ilmenite, and rutile. Monazite grains (up to $300 \mu \mathrm{m}$ ) occur as inclusions in mesoperthite, quartz, and garnet or interstitially between these minerals. Zircon grains (up to $200 \mu \mathrm{m}$ ) occur both interstitially and as inclusions in mesoperthite, quartz, garnet, and monazite. Commonly, two or three zircon grains are clustered together. The whole rock has relatively high $\mathrm{Na}_{2} \mathrm{O}+\mathrm{K}_{2} \mathrm{O}$, FeO *, $\mathrm{Zr}, \mathrm{Nb}, \mathrm{Y}, \mathrm{Ga}(\mathrm{Ga} / \mathrm{Al}=3.6)$, and rare earth elements (REE) and low $\mathrm{CaO}$ and $\mathrm{Sr}$ (table 1), features of A-type granites (Whalen et al. 1987).

The psammitic gneiss occurs as a layer several meters to a few tens of meters thick with quartzofeldspathic and peraluminous bands. The former have a granoblastic texture and consist mainly of anhedral garnet, plagioclase, and quartz. The latter bands contain thin $(<10 \mathrm{~mm})$ garnet-sillimaniterich layers and aluminous mineral lenses consisting of euhedral garnet interspersed with spinel, biotite, rutile, and ilmenite. The sample for Sm-Nd dating (SS97021208-1) was collected from a quartzofeldspathic band containing fractured almandine and pyrope-rich garnets $\left(\mathrm{Alm}_{52-55^{-}}\right.$ $\mathrm{Pyr}_{41-44} \mathrm{Grs}_{3-4} \mathrm{Sps}_{\leq 1}$ ) up to $3 \mathrm{~mm}$ diameter, partly altered to fine-grained mica, as in the granitic gneiss.

The sample of mafic granulite (SS97021303B) was collected from a mafic layer $1 \mathrm{~m}$ to a few tens of meters in thickness. The rock has a tholeiitic composition consistent with an igneous protolith (table 1). It consists mainly of plagioclase, clinopyroxene (28-32 modal vol.\%), and orthopyroxene ( $\leq 7$ modal vol. $\%$ ), with minor apatite, ilmenite, and magnetite. The pyroxene crystals are euhedral to subhedral and usually up to $1 \mathrm{~mm}$ in diameter. Magnetite is common, surrounding pyroxene and also found along grain boundaries and fractures in quartz and plagioclase.

\section{Experimental Procedure}

SHRIMP Zircon and Monazite U-Pb Analyses. Zircon and monazite from granitic gneiss SS97021307 were dated using the SHRIMP II at the Australian National University (ANU), Canberra. The zircon was analyzed during two analytical sessions. For the first session, $\sim 50$ grains were mounted with zircon standards SL13 (238 ppm U) and AS3 (1099 $\mathrm{Ma})$. For the second, $\sim 200$ grains were mounted with SL13 and standard FC1 (1099 Ma). A new mount was required for the second session because some of the zircon grains in the original mount came loose during repolishing.

The analytical conditions for both sessions were similar. A 3-5-nA $\mathrm{O}_{2}^{-}$primary ion beam was focused to an $\sim 25-\mu \mathrm{m}$-diameter probe. Secondary ions were measured by single collector by magnet cycling. $\mathrm{Pb} / \mathrm{U}$ calibration uncertainties for the two sessions were $0.45 \%$ and $0.25 \%$, respectively. Model $\mathrm{Pb}$ compositions (Cumming and Richards 1975) that were consistent with the ages of individual zircons were used for the common $\mathrm{Pb}$ corrections, which were calculated using ${ }^{204} \mathrm{~Pb}$. Secondary ion ratios were calculated by linear interpolation or spline fits, depending upon the homogeneity of individual analyzed areas. Heterogeneity, particularly in $\mathrm{Pb}$ content, is reflected in the 
Table 1. Whole-Rock Compositions of Three Mt. Riiser-Larsen Samples Analyzed for Geochronology: Granitic Gneiss (SS97021307), Psammitic Gneiss (SS97021208-1), and Mafic Granulite (SS97021303B)

\begin{tabular}{|c|c|c|c|}
\hline & SS97021307 & SS97021208-1 & SS97021303B \\
\hline \multicolumn{4}{|c|}{$\begin{array}{l}\text { X-ray fluorescence spectroscopy } \\
(\text { wt. \%): }\end{array}$} \\
\hline $\mathrm{SiO}_{2}$ & 68.15 & 75.80 & 49.08 \\
\hline $\mathrm{TiO}_{2}$ & .33 & .36 & .86 \\
\hline $\mathrm{Al}_{2} \mathrm{O}_{3}$ & 16.26 & 11.85 & 14.15 \\
\hline $\mathrm{Fe}_{2} \mathrm{O}_{3}$ & 4.12 & 5.01 & 13.62 \\
\hline $\mathrm{MnO}$ & .02 & .06 & .18 \\
\hline $\mathrm{MgO}$ & 1.04 & 1.76 & 8.43 \\
\hline $\mathrm{CaO}$ & 1.86 & 1.89 & 11.50 \\
\hline $\mathrm{Na}_{2} \mathrm{O}$ & 3.08 & 1.96 & 1.56 \\
\hline $\mathrm{K}_{2} \mathrm{O}$ & 5.00 & 1.64 & .43 \\
\hline $\mathrm{P}_{2} \mathrm{O}_{5}$ & .07 & .00 & .02 \\
\hline Total & 99.93 & 100.34 & 99.83 \\
\hline $\mathrm{FeO}^{\star}$ & 3.75 & 4.51 & 12.26 \\
\hline $\mathrm{FeO}^{\star} / \mathrm{MgO}$ & 3.59 & 2.56 & 1.45 \\
\hline $\mathrm{Ba}(\mathrm{ppm})$ & 741.2 & 338.3 & 10.9 \\
\hline Co (ppm) & 11.0 & 13.2 & 53.2 \\
\hline $\mathrm{Cr}(\mathrm{ppm})$ & 15.1 & 98.8 & 281.5 \\
\hline $\mathrm{Cu}(\mathrm{ppm})$ & .5 & 18.1 & 76.5 \\
\hline $\mathrm{Nb}(\mathrm{ppm})$ & 17.0 & 7.4 & 2.3 \\
\hline $\mathrm{Ni}(\mathrm{ppm})$ & 4.6 & 9.4 & 140.4 \\
\hline $\mathrm{Rb}(\mathrm{ppm})$ & 167.5 & 39.3 & 8.3 \\
\hline $\mathrm{Sr}(\mathrm{ppm})$ & 91.2 & 165.3 & 89.7 \\
\hline $\mathrm{V}$ (ppm) & 11.4 & 61.4 & 256.4 \\
\hline $\mathrm{Y}(\mathrm{ppm})$ & 127.3 & 29.9 & 21.8 \\
\hline $\mathrm{Zn}(\mathrm{ppm})$ & 25.9 & 33.9 & 102.9 \\
\hline $\mathrm{Zr}(\mathrm{ppm})$ & 325.2 & 137.8 & 37.3 \\
\hline \multicolumn{4}{|c|}{$\begin{array}{l}\text { Inductively coupled plasma-mass } \\
\text { spectrometry (ppm): }\end{array}$} \\
\hline $\mathrm{Ga}$ & 31 & 13 & 15 \\
\hline $\mathrm{Ge}$ & 1.4 & 1.1 & 1.4 \\
\hline $\mathrm{Sn}$ & 1 & $<1$ & 2 \\
\hline $\mathrm{La}$ & 213 & 39.0 & 3.53 \\
\hline $\mathrm{Ce}$ & 406 & 67 & 9.1 \\
\hline $\operatorname{Pr}$ & 40.9 & 6.37 & 1.34 \\
\hline $\mathrm{Nd}$ & 151 & 23.0 & 7.31 \\
\hline $\mathrm{Sm}$ & 31.0 & 3.77 & 2.55 \\
\hline $\mathrm{Eu}$ & 1.954 & 1.323 & .816 \\
\hline $\mathrm{Gd}$ & 24.9 & 3.87 & 3.42 \\
\hline $\mathrm{Tb}$ & 4.55 & .72 & .67 \\
\hline Dy & 23.5 & 4.36 & 4.12 \\
\hline Ho & 4.00 & .92 & .85 \\
\hline $\mathrm{Er}$ & 10.4 & 2.78 & 2.37 \\
\hline $\mathrm{Tm}$ & 1.451 & .412 & .359 \\
\hline $\mathrm{Yb}$ & 7.98 & 2.58 & 2.29 \\
\hline $\mathrm{Lu}$ & 1.115 & .388 & .328 \\
\hline Hf & 12 & 3.1 & .9 \\
\hline $\mathrm{Ta}$ & .5 & .8 & .2 \\
\hline $\mathrm{Pb}$ & 104 & 28 & $<5$ \\
\hline Th & 147 & 2.16 & $<.05$ \\
\hline $\mathrm{U}$ & 6.94 & .34 & $<.05$ \\
\hline
\end{tabular}

larger analytical uncertainties for those measurements.

Twelve monazite grains, selected for their high clarity and lack of inclusions, were mounted for SHRIMP analysis, along with grains of reference monazite WB.T.329 from Thompson Mine, Manitoba (1766 Ma; $2100 \mathrm{ppm} \mathrm{U})$. The monazite grains were also analyzed during two analytical sessions. For the first session, an $\sim 0.2-\mathrm{nA}$ primary $\mathrm{O}_{2}^{-}$ion beam was focused to $\sim 5 \mu \mathrm{m}$ diameter. A small correction $\left(1.3 \times 10^{-6} \mathrm{c} / \mathrm{s} / \mathrm{ppm} \mathrm{Th}\right)$ for a Th-related isobaric interference, possibly $\mathrm{ThNdO}_{2}^{2+}$ (Stern and Sanborn 1998), was applied to ${ }^{204} \mathrm{~Pb}$. For the second session, a primary ion beam of $\sim 3.5 \mathrm{nA}$ was focused 
to an $\sim 25-\mu$ m-diameter spot, improving the analytical precision, and the isobar affecting ${ }^{204} \mathrm{~Pb}$ was eliminated by energy filtering. The uncertainty in the $\mathrm{Pb} / \mathrm{U}$ calibration was $1.2 \%$ for session 1 and $0.4 \%$ for session 2 . Th/U correction factors, determined from the $\mathrm{Pb}$-ThO/UO isochron (Williams et al. 1996) were 0.873 for session 1 and 0.799 for session 2. Common $\mathrm{Pb}$ was corrected using ${ }^{204} \mathrm{~Pb}$ and a model 2.48-Ga $\mathrm{Pb}$ isotopic composition (Cumming and Richards 1975).

Ages were calculated using the constants recommended by the Subcommission on Geochronology (Steiger and Jäger 1977). Before analysis, the zircon internal growth textures were documented by cathodoluminescence (CL) imaging using a Hitachi S-2250N scanning electron microscope. They were imaged again after analysis, and the monazites were imaged by backscattered electron SEM at both the ANU and the National Institute of Polar Research, Japan.

Mineral Sm-Nd Analyses. Sm-Nd mineral isochrons were constructed for samples SS97021307, SS97021208-1, and SS97021303B. Garnet, pyroxene, felsic mineral, and ferromagnetic mineral concentrates were prepared by isodynamic separator, heavy liquids, and handpicking. The garnet fragments from SS97021307 were further separated by handpicking into either a dark-color garnet concentrate that was rich in fine inclusions of monazite and ilmenite or a relatively inclusion-poor light-color garnet concentrate.

The garnet concentrates and garnet-bearing whole-rock fractions were dissolved in HF in a Teflon pressure vessel (Krogh 1973) at $210^{\circ} \mathrm{C}$ for $1 \mathrm{wk}$. The other mineral concentrates and powdered whole-rock fractions (100-200 mg, depending on $\mathrm{Nd}$ concentration) were dissolved in acid in Teflon bottles at $110^{\circ} \mathrm{C}$ for $1 \mathrm{wk}$.

To determine the effects of monazite and/or apatite inclusions on the mineral isochron (cf. Zhou and Hensen 1995; Thöni 2002) for SS97021307, an attempt was made to extract monazite inclusions from the dark-color and light-color garnet concentrates and to separate monazite and apatite inclusions from the felsic mineral concentrate. Powdered garnet concentrates were leached in $6 \mathrm{~N} \mathrm{HCl}$ at $150^{\circ} \mathrm{C}$ for $2 \mathrm{~h}$. The leachate was analyzed as garnet leachate. The residual garnet was divided into two fractions, residual dark garnet and residual light garnet. Similarly, the powdered felsic mineral concentrate, which consisted mainly of feldspar and quartz with minor amounts of monazite and/ or apatite, was leached in $2.5 \mathrm{~N} \mathrm{HCl}$ at $100^{\circ} \mathrm{C}$ for $20 \mathrm{~min}$. The leachate was analyzed as felsic mineral leachate and the leached felsic minerals as residual felsic fraction. The untreated felsic mineral concentrate (felsic fraction) was also analyzed.

$\mathrm{Sm}$ and $\mathrm{Nd}$ concentrations were measured using ${ }^{149} \mathrm{Sm}-{ }^{150} \mathrm{Nd}$ mixed spikes and the methods of Kagami et al. (1982, 1987). Total blanks were 0.025 $\mathrm{ng}$ for $\mathrm{Sm}$ and $0.220 \mathrm{ng}$ for $\mathrm{Nd}$. The $\mathrm{Sm}$ and $\mathrm{Nd}$ isotope compositions were measured on the MAT262 mass spectrometer at the Department of Geology, Faculty of Science, Niigata University. Isochron ages were calculated using the computer program by Kawano (1994), based on the equation of York (1966) and the decay constants: $\lambda^{147} \mathrm{Sm}=$ $6.54 \times 10^{-12} \mathrm{yr}^{-1}$ (Lugmair and Marti 1978) and $\lambda^{187} \mathrm{Rb}=1.42 \times 10^{-11} \mathrm{yr}^{-1}$ (Steiger and Jäger 1977).

\section{Results}

SHRIMP U-Pb Zircon Ages. CL imaging before SHRIMP analysis revealed that most of the zircon grains consist of a core surrounded by a thick overgrowth (fig. 4). The cores are mostly angular to rounded zircon fragments, range from very weakly to moderately luminescent, and have textures ranging from apparently homogeneous to euhedrally zoned. Three types of cores can be recognized: (1) cores with moderate CL that commonly are angular fragments of grains with concentric oscillatory zoning (moderate CL and angular [MA] cores), (2) cores with weak to very weak CL that have a euhedral outline (i.e., appear to be intact) and remnant euhedral zoning (weak CL and euhedral [WE] cores), and (3) cores with weak to very weak CL that have a rounded outline and commonly little or no zoning (weak CL and rounded [WR] cores). The overgrowths are moderately luminescent and show only weak broad concentric or sector zoning even when the images are digitally enhanced.

The analyses show a range of chemical compositions that correlate with textural setting (table 2, available in the online edition or from the Journal of Geology office; fig. 5). The median U contents of the cores and overgrowths are rather similar (cores, $1500 \mathrm{ppm}$; overgrowths, $1000 \mathrm{ppm}$ ), and both are higher than the average for zircon from felsic igneous rocks ( 500 ppm), but the range of compositions in the cores is much larger than that in the overgrowths. Whereas the overgrowths, with one exception that is texturally unusual, range only between 680 and $1780 \mathrm{ppm} U$ and have a nearly constant $\mathrm{Th} / \mathrm{U}(\sim 0.2)$, the cores range from 250 to $4670 \mathrm{ppm} \mathrm{U}$ and have $\mathrm{Th} / \mathrm{U}$ values ranging from 0.02 to 1.46. The compositions differ with core type. The WE and WR cores have consistently low $\mathrm{Th}$ (most $<200 \mathrm{ppm}$ ) and high U (median $2300 \mathrm{ppm}$ ), hence their low $\mathrm{Th} / \mathrm{U}(<0.14)$. In contrast, the MA 

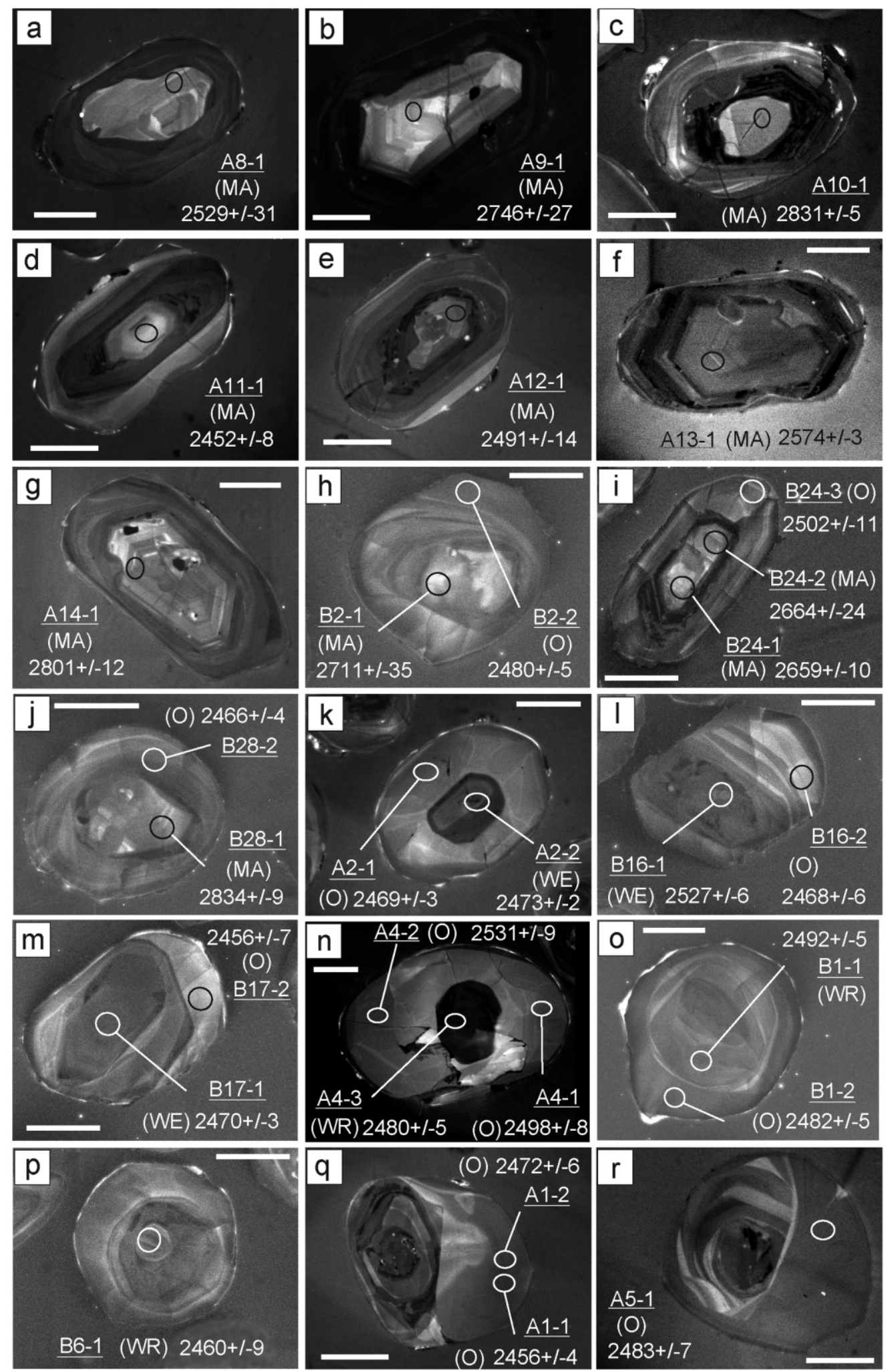

Figure 4. Cathodoluminescence (CL) images of selected analyzed zircon grains. Ellipses mark analyzed areas. $a-j$, Angular cores with moderate CL $(M A)$ and overgrowth; $k-m$, euhedral cores with weak CL $(W E)$ and overgrowth; $n-$ $p$, rounded cores with weak CL $(W R)$ and overgrowth; $q, r$ : overgrowths. Scale bar $=50 \mu \mathrm{m}$. 


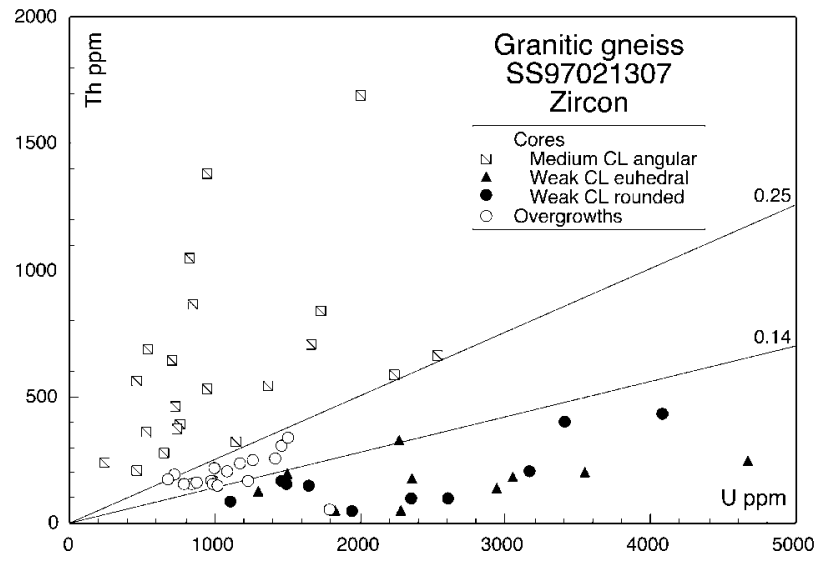

Figure 5. Plot of Th and $U$ contents of zircon from granitic gneiss SS97021307 showing the distinctive compositions of the four main zircon types.

cores have higher and a larger range of Th contents, and hence, $\mathrm{Th} / \mathrm{U}$ is always greater than 0.25 (median 0.52).

A similar relationship to textural setting is seen in the isotopic compositions (fig. 6). The analyses of the overgrowths form a relatively tight, nearconcordant cluster with a mean apparent age of $\sim 2.5 \mathrm{Ga}$. Many analyses of the weak-CL cores (WE and WR) fall within the same cluster, but some are strongly discordant. The fact that the ${ }^{207} \mathrm{~Pb} /{ }^{206} \mathrm{~Pb}$ apparent ages of the discordant cores are very similar to those in the main cluster indicates that the discordance is due to very recent (Mesozoic or later) loss of radiogenic $\mathrm{Pb}$. In contrast, the analyses of the MA cores, although mostly near concordant, yield a wide range of apparent ages $(2.83-2.45 \mathrm{Ga})$. Three analyses are strongly discordant (fig. 6), also indicative of $\mathrm{Pb}$ loss, but the timing of $\mathrm{Pb}$ loss cannot be determined because, unlike the discordant WE and WR cores, the ${ }^{207} \mathrm{~Pb} /{ }^{206} \mathrm{~Pb}$ age of the discordant MA cores before $\mathrm{Pb}$ loss cannot be inferred.

Although most of the analyses lie close to concordia, the pattern of discordance is actually more complex. Many of the analyses are reversely discordant beyond both counting errors and all identified sources of $\mathrm{Pb} / \mathrm{U}$ calibration error. This applies particularly to the analyses of the overgrowths and is a feature of the analyses from both sessions. It is thought unlikely that this is a systematic matrixdependent calibration error. The only such effect identified is an overestimation of $\mathrm{Pb} / \mathrm{U}$ that occurs when analyzing zircon with $U$ contents $>2500 \mathrm{ppm}$ (Williams and Hergt 2000). The few analyses from this sample that exceed this threshold have been corrected as necessary $(2 \% / 1000 \mathrm{ppm} U>2500$ ppm), but most of the reversely discordant analyses have $U$ contents that are much lower.

Each zircon type has a distinctive range of ages and compositions that indicates the presence of at least three principal generations of zircon growth: MA cores, WE and WR cores, and overgrowths (fig. 7). The wide range of composition and apparent age of the MA cores is consistent with their being derived from a variety of igneous sources of a variety of ages or originating from a single source at least $2.83 \mathrm{Ga}$ old and having suffered variable $\mathrm{Pb}$ loss at $\sim 2.5 \mathrm{Ga}$. Given that there is no correlation between apparent age and Th or U content, the second option is considered less likely.

The WE and WR cores, with their much higher average $\mathrm{U}$ contents and consistently much lower $\mathrm{Th} / \mathrm{U}$ and apparent age, almost certainly represent a different primary source and/or generation of zircon growth. This is borne out by the much smaller range in their apparent ages, although even omitting the analyses strongly affected by $\mathrm{Pb}$ loss, neither the WE nor WR cores have a uniform radiogenic ${ }^{207} \mathrm{~Pb} /{ }^{206} \mathrm{~Pb}$ within error. Such low $\mathrm{Th} / \mathrm{U}$ values are commonly found in metamorphic zircon grown in metasediments in the presence of a Thrich mineral such as monazite. The euhedral form and remnant euhedral zoning of the WE cores argues against this zircon being metamorphic, however. More likely, it has formed in a peraluminous environment in the presence of moderate amounts of partial melt. It is not possible to determine the probable age of the WE cores with any reasonable level of confidence. Their ${ }^{207} \mathrm{~Pb} /{ }^{206} \mathrm{~Pb}$ apparent ages scatter far more than expected from the analytical errors (MSWD $=62$ ), even when the two highly discordant analyses are omitted (MSWD $=42$ ).

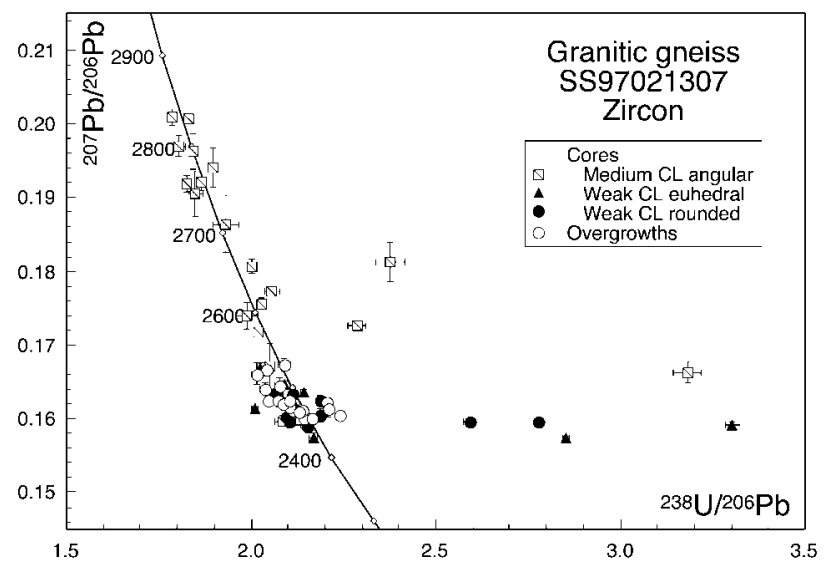

Figure 6. Tera-Wasserburg concordia diagram for zircon from granitic gneiss SS97021307. 


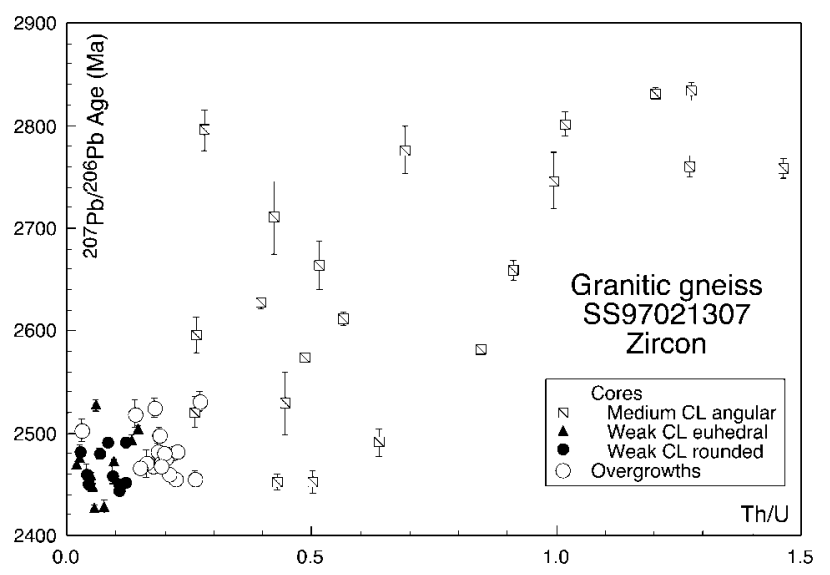

Figure 7. Plot of apparent age versus $\mathrm{Th} / \mathrm{U}$ for zircon from granitic gneiss SS97021307 showing the wide range in age and composition of the moderate CL and angular $(M A)$ cores compared with that of the other zircon types.

Not even the three highest apparent ages are equal within error. All that can be said is that the apparent age of the WE cores is $\sim 2.47 \mathrm{Ga}$. The apparent ages of the WR cores are much less scattered (MSWD $=20$ ), although the scatter is not further reduced when the two strongly discordant analyses are omitted. It is possible to divide the analyses into two groups, each giving a constant age within error. The four highest ages are equal at $2488 \pm 8(\mathrm{t} \sigma) \mathrm{Ma}$, and the six lowest are equal at $2450 \pm 4(\mathrm{t} \sigma) \mathrm{Ma}$. There is no independent reason to expect these ages to have specific geological significance, however. A reasonable interpretation of the analyses is that the WR cores are at least $2488 \pm 8 \mathrm{Ma}$ old.

The overgrowths, from their textures, are almost certainly metamorphic. Despite their similarity in apparent age to the WE and WR cores, their distinctively higher and more uniform $\mathrm{Th} / \mathrm{U}$ ratios indicate that they represent a separate and, given that they overgrow the cores, later episode of zircon growth. One might expect the overgrowths to have formed during a single thermal event, but like the cores, they yield a range of apparent ages, although less scattered than those of the cores (MSWD = 9.2). Even individual overgrowths give a range of ages, e.g., grain A4 $(2531 \pm 9$ and $2498 \pm 8 \mathrm{Ma})$ and grain A1 (2472 \pm 6 and $2456 \pm 4 \mathrm{Ma})$. Much of the scatter is contributed by the five highest ages, omitting which reduces the MSWD to 4.1. Omitting three low ages leaves 10 analyses almost equal within error, giving a weighted mean age of $2473 \pm 4(\mathrm{t} \sigma)$ Ma. The omitted five highest ages are almost equal within error at $2514 \pm 12$ (t $\sigma)$ Ma. These results suggest that the zircon overgrowths with weak broad concentric or sector zoning crystallized at $\sim 2.51-2.47 \mathrm{Ga}$.

SHRIMP U-Pb Monazite Ages. Most of the monazite grains consist of a backscattered electron (BSE)-dark core surrounded by an irregular BSElight rim on average $\sim 20 \mu \mathrm{m}$ thick (fig. 8). Two of the selected grains also contained an even darker inner core, and two consisted entirely of rim material (fig. $8 g, 8 i$ ). The BSE-dark monazite has a mottled texture, whereas the BSE-light monazite has either euhedral or sinuous zoning.

The six analyses from the first session (two from the central regions of each of three grains) are concordant or near concordant, with a range of radiogenic ${ }^{207} \mathrm{~Pb} /{ }^{206} \mathrm{~Pb}$ that slightly exceeds that expected from the analytical uncertainties. Omitting the lowest value eliminates the scatter, leaving five analyses yielding a weighted mean age of $2485 \pm$ $6(\mathrm{t} \sigma)$ Ma. During the second session, nine more cores, two inner cores, five overgrowths, and one grain of overgrowth material (grain 7, fig. 8j) were analyzed. Most of the isotopic compositions are near concordant (fig. 9), but a few are up to $\sim 4 \%$ discordant. There is a much wider range in ${ }^{207} \mathrm{~Pb} /$ ${ }^{206} \mathrm{~Pb}$ age $(2.50-2.43 \mathrm{Ga})$ than expected from the analytical uncertainties. The variability in ${ }^{207} \mathrm{~Pb} /{ }^{206} \mathrm{~Pb}$ age does not correlate with monazite composition or textural setting, although there is a systematic difference in the Th content, which is lowest in the inner cores $(\sim 70,000 \mathrm{ppm})$, intermediate in the cores, and highest in the overgrowths $(\sim 140,000$ ppm; table 3, available in the online edition or from the Journal of Geology office). The apparent ages of the cores span the entire range, the two inner cores yield apparent ages less than most of the overgrowths, and the mean ages of the overgrowths and cores are indistinguishable. The variation in apparent age correlates more closely with grain selection. The three analyses of grain 5 (overgrowth and two cores, fig. $8 h$ ), for example, yield the same above-average ${ }^{207} \mathrm{~Pb} /{ }^{206} \mathrm{~Pb}$ age of $2488 \pm 4(\sigma) \mathrm{Ma}$. In contrast, the analyses of the inner core and overgrowth of grain 4 (fig. $8 g$ ) yield the much lower age of $2464 \pm 6(\sigma) \mathrm{Ma}$. The five analyses of grain 1 (fig. $8 a, 8 d)$ scatter very slightly, yielding the intermediate age of $2476 \pm 2(\sigma)$ Ma. Grain 8 (fig. $8 k$ ) is notable for both its relatively low average age $(2451 \pm 3[\sigma] \mathrm{Ma})$ and its heterogeneity (two core analyses give ages differing by $28 \mathrm{Ma}$ ).

There are several possible explanations for the dispersion in ${ }^{207} \mathrm{~Pb} /{ }^{206} \mathrm{~Pb}$, including monazite growth over an extended period of time, progressive closure during slow cooling, and isotopic disturbance. The lack of any systematic difference in measured age between inner cores, cores, and over- 

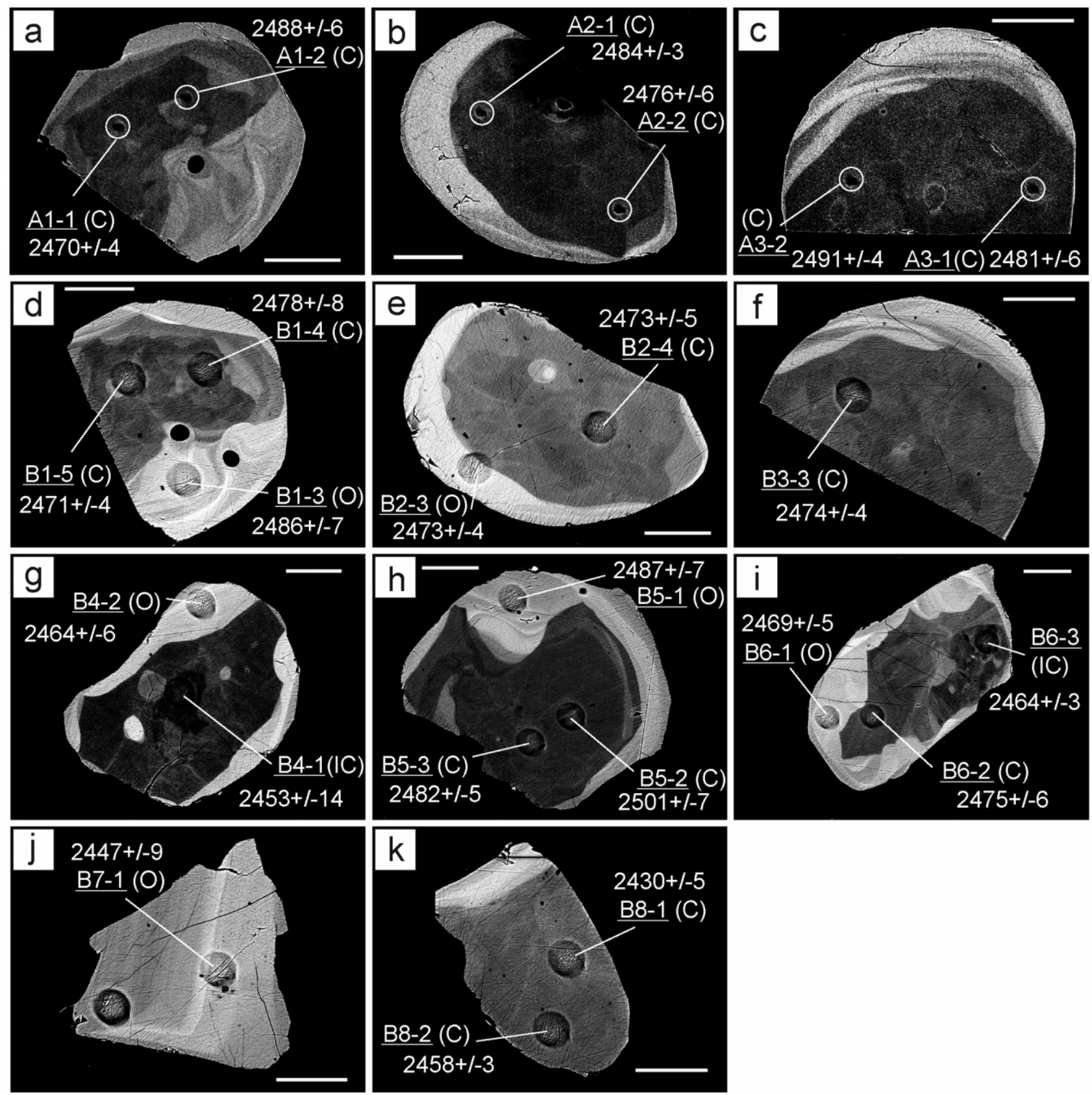

Figure 8. Backscattered electron images of analyzed monazite grains showing the pits left after SHRIMP analysis. $a-c$, Grains 1-3 before repolishing; $d-k$, grains 1-8 after repolishing. Scale bar $=50 \mu \mathrm{m}$.

growths shows that even if each did crystallize at a different time, all record of those age differences has been lost. Progressive closure over nearly 70 $\mathrm{Ma}$ is also unlikely, given that the monazite grains in a single hand specimen probably experienced the same thermal history, and there is no correlation between apparent age and monazite composition.

Given that the biggest differences in apparent age are found between, not within, grains, the most likely explanation for the age range is variable early isotopic disturbance imposed on monazite with an initial relatively small ( $10 \mathrm{~m}$.yr.) range of closure ages. The clustering of the analyses toward the upper end of the age range suggests that the main effect of that disturbance was $\mathrm{Pb}$ loss. Omitting the four analyses that lie well below the main cluster 


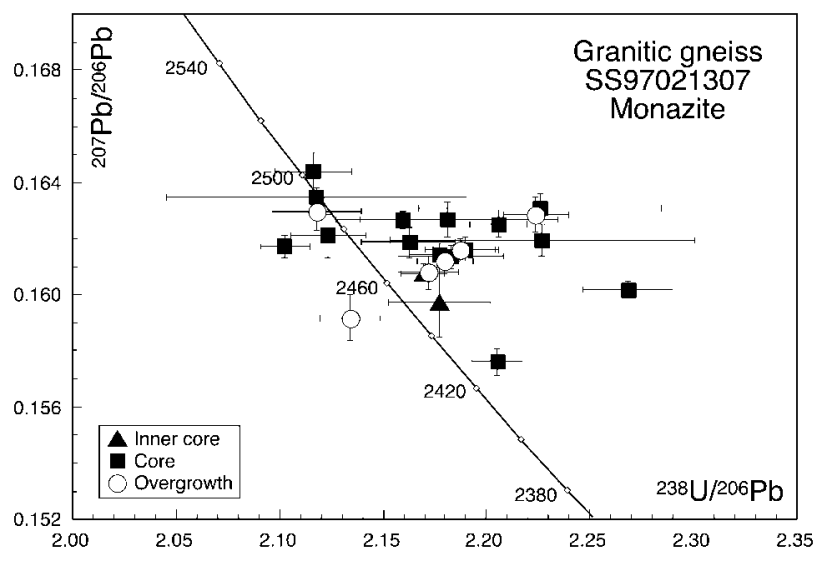

Figure 9. Tera-Wasserburg concordia diagram for monazite from granitic gneiss SS97021307.

greatly reduces the scatter but does not eliminate it (MSWD $=3.8$ ). The remaining outliers are the two highest analyses and one low one, omitting which leaves 16 analyses almost equal within error, yielding a weighted mean age of $2476 \pm 3(\mathrm{t} \sigma) \mathrm{Ma}$. Although this age might still be low because of early $\mathrm{Pb}$ loss, it is our best estimate of the closure age of the bulk of the monazite.

Sm-Nd Whole-Rock-Mineral Isochron Ages. Table 4 summarizes the Sm and Nd compositions of the whole-rock fractions and mineral concentrates. Residual garnet concentrates from the granitic gneiss (SS97021307) had remarkably high Sm and Nd concentrations. The Sm-Nd whole-rock-mineral isochron for the granitic gneiss is moderately well delineated by seven data points and defines an age of $2382 \pm 35 \mathrm{Ma}$ (initial ratio [IR]: $0.50907 \pm$ 0.00022 ; fig. 10A). The garnet leachate is probably dominantly leached monazite. Given its abnormally low $\mathrm{Sm} / \mathrm{Nd}$, the felsic mineral leachate probably includes leached feldspar. It is noteworthy that the leachates plot on the same isochron as the residual mineral concentrates prepared by acid leaching, the whole-rock, and the untreated fractions. The Sm-Nd whole-rock-mineral isochrons for the psammitic gneiss (SS97021208-1) and the mafic granulite (SS97021303B) yield ages of $2365 \pm 22$ $\mathrm{Ma}$ (IR: $0.509199 \pm 0.000071$; fig. $10 B$ ) and $2380 \pm 18 \mathrm{Ma}$ (IR: $0.509448 \pm 0.000022$; fig. 10C), respectively.

The three Sm-Nd isochron ages are mutually indistinguishable within the uncertainties and record the time when the Nd-isotopic system in garnet and pyroxene became closed in this area.

\section{Discussion}

UHT Metamorphism of the Napier Complex. A multievent history has already been proposed to account for the complexities in the geochronology of the Napier Complex (Motoyoshi and Hensen 1989; Hensen and Motoyoshi 1992; Harley and Black 1997). Three different ages have been suggested for the UHT metamorphism: 2.84 Ga (Harley and Black 1997), 2.59-2.55 Ga (e.g., Crowe et al. 2002; Harley 2003), and $2.48-2.45$ Ga (e.g., Grew 1998; Carson et al. 2002; Hokada et al. 2003, 2004; Hokada and Harley 2004).

Working in the Tula Mountains-Scott Mountains region, Harley and Black (1997) identified a UHT metamorphic event that peaked at 2.85-2.82 $\mathrm{Ga}$, overprinting an earlier $(2.98 \mathrm{Ga})$ granulite facies metamorphism. They inferred a prolonged period of UHT metamorphism lasting from $\sim 2.84$ to 2.5-2.4 Ga, followed by amphibolite facies metamorphism and then extremely slow cooling from $\sim 1000^{\circ} \mathrm{C}$ to $600^{\circ}-700^{\circ} \mathrm{C}\left(\sim 1.3^{\circ} \mathrm{C} / \mathrm{m}\right.$.yr. $)$ over a period of $\sim 400 \mathrm{~m}$.yr. The $\sim 2.8-\mathrm{Ga}$ age probably reflects regional magmatism in the Napier Complex (cf. Black et al. 1983a, 1986a, 1986b; Harley and Black 1997; Hokada et al. 2003). Hokada et al. (2003, 2004) measured SHRIMP zircon ages of $\sim 3.3-3.0$ and $\sim 2.52-2.45 \mathrm{Ga}$ on the gneisses at Mt. RiiserLarsen but found minimal evidence of an event at $\sim 2.8 \mathrm{Ga}$ (fig. $2 A$ ). They interpreted $\sim 2.52-2.45 \mathrm{Ga}$ as the main metamorphic age, $2.85-2.79 \mathrm{Ga}$ as the age of an earlier unrelated metamorphism connected to granite magmatism, and minor zircon age clusters at $\sim 3.27$ and $\sim 3.07 \mathrm{Ga}$ as protolith ages of TTG affinity rocks. Carson et al. (2002), working at Tonagh Island, found no record of a $\sim 2.8-\mathrm{Ga}$ event, which is further evidence against pervasive UHT metamorphism at $\sim 2.8 \mathrm{Ga}$ (fig. $2 B$ ). They constrained the age of UHT metamorphism to be $<\sim 2.62 \mathrm{Ga}$, the emplacement age of pre-UHT orthogneiss.

Harley et al. (2001) and Harley (2004) argued that zircon U-Pb data from undeformed leucosomes on McIntyre Island constrain the age of UHT metamorphism to be $\sim 2.59 \mathrm{Ga}$. This is consistent with the suggestion by Crowe et al. (2002), based on SHRIMP dating of mylonitic rocks from Tonagh Island, that the UHT metamorphism predated mylonitization at $\sim 2.55-2.47 \mathrm{Ga}$. They interpreted 2.5-2.4 Ga as the age of the protracted $\mathrm{D}_{3}$ event that produced regional dome and basin structures (James and Black 1981; Sheraton et al. 1987), its associated amphibolite facies metamorphism, and isotopic resetting and zircon growth. Harley (2004) noted that this event was accompanied by fluid cir- 
Table 4. Sm and Nd Concentrations and Isotopic Data for Mt. Riiser-Larsen Minerals and Whole-Rock Fractions or Leachates of Granitic Gneiss (SS97021307), Psammitic Gneiss (SS97021208-1), and Mafic Granulite (SS97021303B)

\begin{tabular}{|c|c|c|c|c|c|}
\hline Sample & $\mathrm{Nd}(\mathrm{ppm})$ & $\mathrm{Sm}(\mathrm{ppm})$ & ${ }^{147} \mathrm{Sm} /{ }^{144} \mathrm{Nd}$ & ${ }^{143} \mathrm{Nd} /{ }^{144} \mathrm{Nd}$ & $(2 \sigma)^{\mathrm{a}}$ \\
\hline \multicolumn{6}{|l|}{ SS97021307: } \\
\hline Residual felsic fraction & 39.9 & 4.98 & .07530 & .510195 & (13) \\
\hline Felsic fraction & 50.2 & 6.51 & .07840 & .510326 & (14) \\
\hline Felsic mineral leachate & -1 & & .08300 & .510357 & (11) \\
\hline Whole-rock fraction & 162 & 32.0 & .1196 & .510961 & (12) \\
\hline Garnet leachate & & & .2050 & .512367 & (14) \\
\hline Residual dark garnet & 15.9 & 49.4 & 1.891 & .538270 & (20) \\
\hline Residual light garnet & 11.9 & 45.1 & 2.305 & .545689 & (22) \\
\hline \multicolumn{6}{|l|}{ SS97021208-1: } \\
\hline Felsic fraction & 21.7 & 1.76 & .04901 & .509995 & (14) \\
\hline Whole-rock fraction & 22.6 & 3.68 & .09830 & .510697 & (14) \\
\hline Garnet fraction & 8.74 & 12.8 & .8878 & .523037 & (14) \\
\hline \multicolumn{6}{|l|}{ SS97021303B: } \\
\hline Felsic fraction & 1.75 & .239 & .08280 & .510748 & (14) \\
\hline Whole-rock fraction & 7.01 & 2.45 & .2112 & .512756 & (9) \\
\hline Pyroxene fraction & 7.44 & 2.89 & .2350 & .513139 & (14) \\
\hline
\end{tabular}

${ }^{a}$ Analytical reproducibility in terms of $2 \sigma$, referring to the last digits.

culation. More recently, Kelly and Harley (2005) concluded that the UHT metamorphism must be older than $2.51 \mathrm{Ga}$ and is probably older than 2.55 $\mathrm{Ga}$. They further suggested that zircon $\mathrm{U}-\mathrm{Pb}$ ages between 2.49 and 2.45 Ga reflect late postpeak zircon growth, not the timing of peak UHT metamorphism.

Many workers have argued, to the contrary, that the metamorphism at $\sim 2.5 \mathrm{Ga}$ (often focused at 2.48-2.47 Ga) was the UHT event (e.g., Grew and Manton 1979; Sandiford and Wilson 1986; Sandiford and Powell 1986; Owada et al. 1994; Grew 1998; Asami et al. 2002; Carson et al. 2002; Hokada et al. 2003, 2004; Hokada and Harley 2004). Carson et al. (2002) pointed out that there are numerous 2.48-2.45-Ga SHRIMP U-Pb zircon ages from Tonagh Island despite the $\mathrm{F}_{2}$ folding associated with the 2 .5-Ga $\mathrm{D}_{3}$ deformation having been less intense there than in the Fyfe Hills (Black and James 1983). Hokada and Harley (2004) recently reported a zircon age of $2.49-2.47$ Ga from UHT leucosome from Mt. Riiser-Larsen and proposed, based on the REE analyses of zircon and coexisting garnet, that the leucosome had crystallized from felsic melt at the end of the UHT event. The two ages proposed for peak UHT metamorphism, 2.59-2.55 and $\sim 2.49-2.47 \mathrm{Ga}$, possibly reflect regional and/or local differences in the degree of isotopic resetting.

The oldest MA zircon cores identified in this study $(\sim 2.8 \mathrm{Ga})$ might be inherited zircon originating from igneous sources related to a $\sim 2.8$-Ga magmatic event in another area (fig. 7). Possibly the younger MA cores $(\sim 2.6 \mathrm{Ga})$ record emplacement of the A-type granite that was the protolith of the orthogneiss, but so few such cores survive that this is hard to verify.

The monazite ages measured in this study $(\sim 2.48$ Ga) are slightly higher than the CHIME monazite ages $(\sim 2.40 \mathrm{Ga})$ reported from Mt. Riiser-Larsen by Asami et al. (2002). They also determined CHIME zircon ages (2.44-2.42 Ga) from Mt. Riiser-Larsen, as well as CHIME monazite $(2.43-2.41 \mathrm{Ga})$, zircon $(\sim 2.43 \mathrm{Ga})$, and xenotime ( 2.43 Ga) ages from several other localities in the Amundsen Bay area (Beaver Island, Reference Peak, and Mt. Cronus). They interpreted the 2.5-2.4-Ga ages as recording the UHT metamorphic event. Black et al. (1984) interpreted isotope dilution-thermal ionization mass spectrometry (ID-TIMS) monazite U-Pb ages of $\sim 2.43 \mathrm{Ga}$ from the Casey Bay area (Field Islands) as recording cooling below $\sim 650^{\circ} \mathrm{C}$ after the $\mathrm{D}_{3}-\mathrm{M}_{3}$ event.

To interpret the $2.51-2.45-\mathrm{Ga}$ SHRIMP apparent ages obtained from the granitic gneiss from Mt. Riiser-Larsen, it is necessary to compare the ages measured on the various zircon types and the monazite. The mean apparent age of the five oldest zircon overgrowths $(2514 \pm 12 \mathrm{Ma})$ is significantly higher than the ages measured on many of the WR and WE cores and even some of the MA cores. This conflicts with the textural evidence that the overgrowths postdate the cores. Either the older overgrowths are a separate generation of zircon growth and those analyses are mixed with core material or the relatively young cores are isotopically disturbed. The similarity of all the overgrowth Th and $\mathrm{U}$ contents argues that they all represent the same growth generation, and the CL imaging shows that 

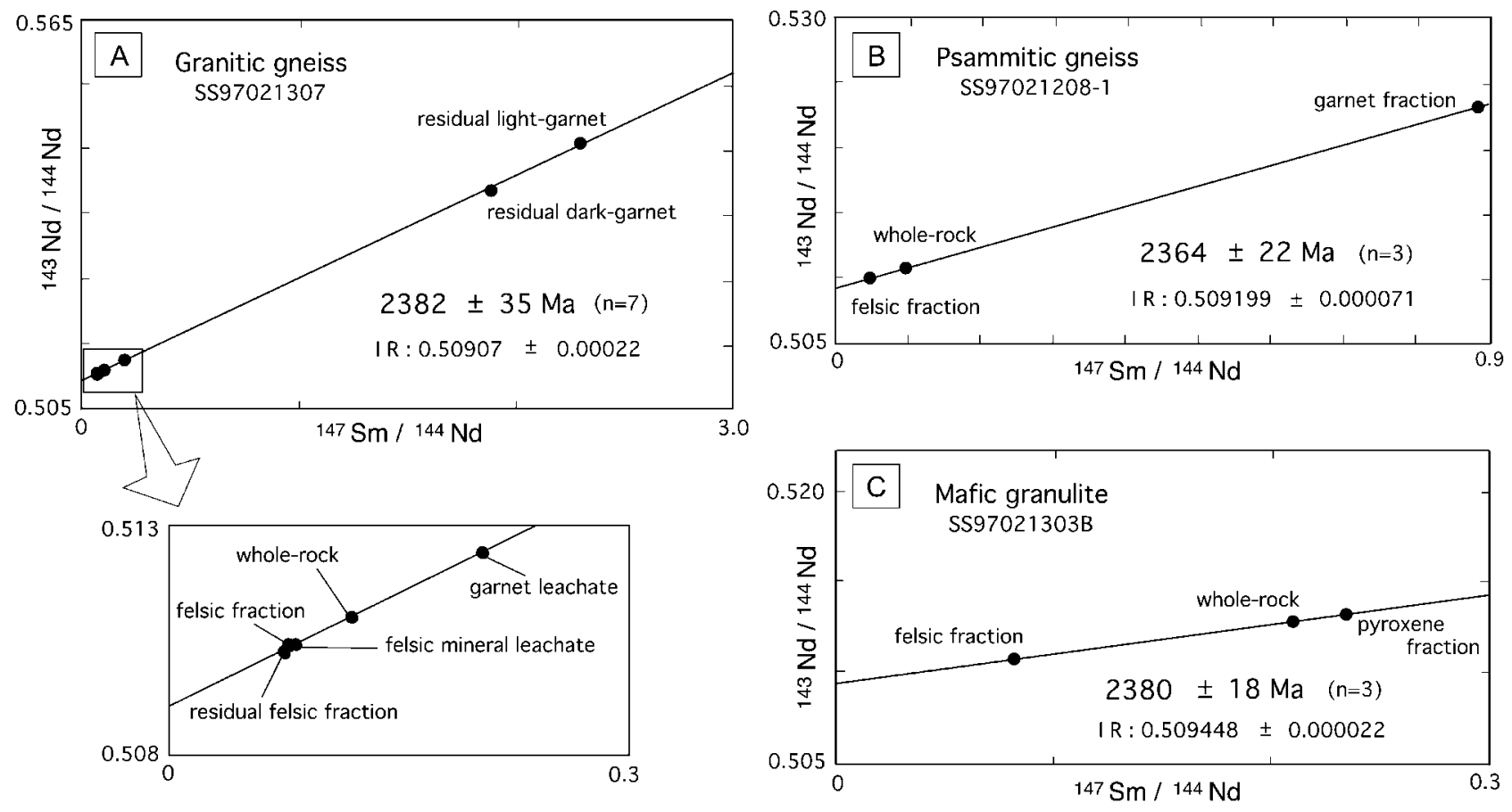

Figure 10. Sm-Nd mineral isochron diagrams for granitic gneiss SS97021307, psammitic gneiss SS97021208-1, and mafic granulite SS97021303B.

the analyses are of purely overgrowth zircon, so the age difference is almost certainly caused by isotopic disturbance of the "young," mostly high-U, cores. The dispersion of ${ }^{207} \mathrm{~Pb} /{ }^{206} \mathrm{~Pb}$ in those cores, and particularly the scatter of very low apparent ages, is good evidence that such disturbance has occurred. Both the WR and WE cores are probably at least as old as $2488 \pm 8 \mathrm{Ma}$.

If one accepts that all the zircon overgrowths are metamorphic, then the metamorphism started at least as early as $2514 \pm 12 \mathrm{Ma}$. The significant range of ages recorded by both the zircon overgrowths and much of the monazite suggests that the metamorphism was a protracted event. The coincidence of zircon overgrowth and monazite ages at $\sim 2.47 \mathrm{Ga}$ possibly reflects initial postpeak cooling. The scattering of even lower ages for both zircon and monazite suggests that temperatures nevertheless remained quite high $\left(\geq 800^{\circ} \mathrm{C}\right)$ for several million years thereafter, causing some diffusive $\mathrm{Pb}$ loss from both minerals. Such prolonged metamorphism $(\sim 2.51-2.47 \mathrm{Ga})$ is consistent with zircon ages measured on paragneiss and leucosome from Mt. Riiser-Larsen by Hokada et al. (2004). The clustering of ages from different zircon types (WE and WR cores and overgrowth) at 2.49-2.47 Ga supports the proposition by Hokada and Harley (2004) that this was the end or waning stage of the UHT event, when the UHT leucosome crystallized to form zircon in the segregations.

Cooling History of Mt. Riiser-Larsen. The period of peak UHT conditions at Mt. Riiser-Larsen was probably relatively short, a few million years at temperatures $>900^{\circ} \mathrm{C}$, because some zircon cores still preserve a higher ${ }^{207} \mathrm{~Pb} /{ }^{206} \mathrm{~Pb}$ than the overgrowths. The volume diffusion coefficients for $\mathrm{Pb}$ in zircon determined by Lee et al. (1997) yield a Pb migration distance of $3.5 \mu \mathrm{m}$ at $900^{\circ} \mathrm{C}, 40-50 \mu \mathrm{m}$ at $1000^{\circ} \mathrm{C}$, and $500 \mu \mathrm{m}$ at $1100^{\circ} \mathrm{C}$ if such temperatures were maintained for $1 \mathrm{~m}$.yr. The experimental data of Cherniak and Watson (2001) suggest volume diffusion of $\mathrm{Pb}$ in zircon of $15 \mu \mathrm{m}$ at $1000^{\circ} \mathrm{C}$ and $50-100 \mu \mathrm{m}$ at $1100^{\circ} \mathrm{C}$ over the same period. The rocks at Mt. Riiser-Larsen therefore probably cooled at a rate of several tens of degrees per million years between the peak temperature of $1100^{\circ} \mathrm{C}$ and $\sim 900^{\circ} \mathrm{C}$.

Some comparative studies of zircon and monazite U-Pb ages from high-grade metamorphic rocks (e.g., Mezger et al. 1992) have found the monazite age to be less than the zircon age of the same rock, leading to the suggestion that monazite has a lower closure temperature for $\mathrm{Pb}$ diffusion than zircon. This conclusion is supported by the results of some 
experimental work (e.g., Smith and Giletti 1997). Other experiments, however, suggest that $\mathrm{Pb}$ diffusion in monazite might be slightly slower than in zircon (Cherniak and Watson 2001; Cherniak et al. 2004) and therefore that the differences between zircon and monazite ages might be determined by other factors such as chemical stability and sensitivity to recrystallization. In the absence of such effects, the primary factors determining the U-Pb closure temperature are the $\mathrm{Pb}$ diffusion coefficient, the grain size (diffusion length), the crystal geometry, and the cooling rate (Dodson 1973; Ganguly and Tirone 1999; Cherniak and Watson 2001).

There are two possible interpretations of the similarities between the zircon and monazite ages from granitic gneiss SS97021307: (1) both minerals crystallized or recrystallized in response to fluid activity at temperatures below their respective closure temperatures for $\mathrm{Pb}$ diffusion or (2) after the peak UHT metamorphism, the region cooled through the closure temperatures of both minerals very rapidly. The ID-TIMS U-Pb ages of zircon $(22.46 \mathrm{Ga})$ and monazite $(2.43 \mathrm{Ga})$ from the Napier Complex in the Casey Bay area have been interpreted as the age of cooling to the respective zircon and monazite blocking temperatures following the $\mathrm{D}_{3}-\mathrm{M}_{3}$ event (Black et al. 1984). However, the gneisses of the Mt. Riiser-Larsen area were only weakly affected by $\mathrm{D}_{3}$ $\mathrm{M}_{3}$, and the similarity between the ages measured on monazite cores and overgrowths, zircon overgrowths, and zircon WR and WE cores cannot be explained simply by the action of fluids at relatively low temperatures. The fact that most of the $50-\mu \mathrm{m}$ zircon overgrowths and $200-\mu \mathrm{m}$ monazites record the same age, $2473 \pm 4$ and $2476 \pm 3$ (t $\sigma)$ $\mathrm{Ma}$, respectively, is consistent with the postpeak cooling at Mt. Riiser-Larsen having been relatively rapid. Depending on the assumed difference in the closure temperatures for $\mathrm{Pb}$ diffusion in the two minerals, the cooling rate was either $\sim 50^{\circ}-60^{\circ} \mathrm{C} /$ m.yr. $\left(\sim 700^{\circ} \mathrm{C}\right.$ for monazite; cf. Smith and Giletti $1997)$ or $\sim 10^{\circ}-15^{\circ} \mathrm{C} / \mathrm{m}$.yr. $\left(\sim 1050^{\circ} \mathrm{C}\right.$ for monazite; cf. Cherniak et al. 2004), assuming a zircon closure temperature of $900^{\circ}-950^{\circ} \mathrm{C}$ (Lee et al. 1997; Cherniak and Watson 2001).

Proposed closure temperatures for the $\mathrm{Sm}-\mathrm{Nd}$ system in garnet range from $600^{\circ}$ to $850^{\circ} \mathrm{C}$ (Möller et al. 2002). The closure temperature probably depends on the composition of the garnet and adjacent minerals, the diffusion distance (domain size), and other factors such as peak and retrograde metamorphic temperatures and the cooling rate (Burton et al. 1995; Ganguly et al. 1998; Scherer et al. 2000; Möller et al. 2002). This makes it difficult to relate experimental diffusion data to the gneisses of the
Napier Complex, particularly given the abnormally high temperature and long duration of the metamorphism. Mezger et al. (1992) empirically estimated closure temperatures of $600^{\circ}-650^{\circ} \mathrm{C}$ for the $\mathrm{Sm}-\mathrm{Nd}$ system in almandine garnet from metarhyolite and metapelite from a Late Archean highgrade metamorphic terrane cooled slowly to a stable steady state geotherm.

The Sm-Nd mineral isochron ages of $\sim 2.38 \mathrm{Ga}$ measured in this study probably record cooling below $600^{\circ}-700^{\circ} \mathrm{C}$, as previously proposed based on petrological data. These ages are significantly less than the zircon and monazite ages $(\sim 2.47 \mathrm{Ga})$. It is considered more probable that the age difference is evidence for slow cooling at midcrustal levels between $\sim 2.49-2.47$ and $\sim 2.38 \mathrm{Ga}$ rather than for a separate $\sim 2.38$-Ga event. The calculated cooling rate between $\sim 2.49-2.47$ and $\sim 2.38 \mathrm{Ga}$ is either $<1^{\circ} \mathrm{C} / \mathrm{m}$.yr., if the closure temperature of monazite is less than that of zircon (Smith and Giletti 1997), or $2^{\circ}-4^{\circ} \mathrm{C} / \mathrm{m}$.yr., if the closure temperature of zircon is less than that of monazite (Cherniak et al. 2004). More work is needed, however, to determine the effects of later fluid or igneous activity, for example, the intrusion of tholeiites during the waning stages of granulite facies metamorphism (Sheraton and Black 1981).

Tectonothermal Model for the 2.5-Ga Metamorphism. Sandiford (1985) and Harley and Black (1987) proposed a thermal model for UHT metamorphism of the Napier Complex in which extremely high peak temperatures $\left(>1000^{\circ} \mathrm{C}\right)$ were followed by isobaric cooling to stable geothermal conditions $\left(\sim 700^{\circ} \mathrm{C}\right)$ at middle to lower crustal levels. Any tectonothermal model of UHT metamorphism in the complex must explain how temperatures in the lower crust (25-40-km depth) were raised to $>1000^{\circ} \mathrm{C}$ on a regional scale.

Contrasting tectonothermal models have been proposed for UHT metamorphism in the Napier Complex. A continental collision and thickening model (Ellis 1987; Harley 1989, 2004) suggests crustal thickening, lithosphere removal, and subsequent hot asthenospheric mantle rise to provide extremely high heat input into the lower crust, resulting in UHT metamorphism. Ellis (1987) proposed a clockwise prograde $P T$ path, in which the early stages of UHT metamorphism were at relatively high pressure, then followed by decompression, and finally near isobaric cooling. His model is principally based on the strong depletion in heavy rare earth (HREE) elements in some Napier orthogneisses. That depletion requires high-pressure conditions to stabilize garnet as a major restite phase in the magmatic pro- 
tolith. However, as demonstrated by Black et al. (1986b), Harley and Black (1987), and Hokada et al. (2003), SHRIMP data from the Napier orthogneisses indicate that their protolith formed much earlier than the peak metamorphic event.

Harley (2004) recently proposed a model for the metamorphism involving extensional collapse accompanied by isothermal decompression and isobaric cooling. The principal evidence for decompression at high temperatures $\left(\sim 1050^{\circ} \mathrm{C}\right)$ is the partial breakdown of garnet to sapphirine + orthopyroxene + sillimanite at Tonagh Island and to sapphirine + orthopyroxene + quartz at Mt. Renouard (Hollis and Harley 2002). Hollis and Harley (2002) pointed out the regional-scale significance of this UHT decompression event and suggested that it was followed by near-isobaric cooling. Such decompression before isobaric cooling probably indicates short-lived extensional crustal thinning following the removal of mantle lithosphere (Harley 2003, 2004).

Numerical modeling of the thermal evolution of the lithospheric mantle (Arnold et al. 2001) suggests that continental collision, lithosphere removal, and asthenospheric heat advection would result in abnormally high temperatures at lower crustal levels shortly (1-10 m.yr.) after the rise of the mantle. Furthermore, this thermal anomaly could be maintained for a relatively long time $(\sim 100$ m.yr.). The tectonothermal model of asthenospheric mantle uprise is consistent with the more protracted UHT conditions and slower cooling favored by many authors. It is also more consistent with our interpretation that HT conditions $\left(\geq 800^{\circ} \mathrm{C}\right)$ lasted $\sim 40$ m.yr. $(\sim 2.51-2.47 \mathrm{Ga})$ and were followed by very slow cooling $\left(\leq 4^{\circ} \mathrm{C} / \mathrm{m}\right.$.yr.) until $\sim 2.38 \mathrm{Ga}$.

The rise of asthenospheric mantle can account for the abnormal geotherm over a wide area, but achieving peak temperatures $>1000^{\circ} \mathrm{C}$ for a short period (a few million years) probably requires the intrusion of magma (Westphal et al. 2003). Sandiford and Powell (1986), Motoyoshi and Hensen (1989), and Hensen and Motoyoshi (1992) argued that magmatism was the primary heat source for the UHT metamorphism of the Napier Complex. Based on the occurrence of sapphirine-quartzorthopyroxene symplectites that have the same bulk composition as cordierite, Motoyoshi and Hensen (1989) inferred a counterclockwise prograde $P T$ path at Mt. Riiser-Larsen. Hensen and Motoyoshi (1992) proposed that the heat for the UHT metamorphism was provided by magmatic accretion above the present level of exposure. The onedimensional thermal conductive model of Annen and Sparks (2002) simulated the thermal evolution at deeper crustal levels induced by repeated intrusion of basaltic sills. The results obtained for moderate geothermal gradients $\left(10^{\circ}-30^{\circ} \mathrm{C} / \mathrm{km}\right)$ in the presence of cool lithospheric mantle demonstrate that after magma input ceases, the initially high conductive heat flux rapidly decreases, resulting in the decay of the thermal anomaly. The circulation of $\mathrm{CO}_{2}$-rich fluids might enhance the transmission of heat and contribute to heating and cooling of dry rocks under UHT conditions at lower to midcrustal levels (Tsunogae et al. 2002). Annen and Sparks (2002) calculated that rocks at $20-\mathrm{km}$ depth would cool from $800^{\circ}$ to $650^{\circ} \mathrm{C}$ in $1 \mathrm{~m}$.yr. This calculation is not directly applicable to the rocks at Mt. RiiserLarsen, where pressures were high and there were no melts. However, melt-free conditions may promote cooling because there is no release of latent heat of crystallization. We infer an actual cooling rate of $10^{\circ}-60^{\circ} \mathrm{C} / \mathrm{m}$.yr. immediately after peak metamorphism, which may be enhanced by one or more periods of decompression (Hollis and Harley 2002). If there were in fact two periods of peak UHT metamorphism (at $\sim 2.59-2.55$ and $\sim 2.49-2.47 \mathrm{Ga}$ ), it is not necessary to postulate that the vast area of the Napier Complex cooled all at once. The problem of the missing heat source above the present level of exposure remains. We favor the composite thermal model in which heat originating from the rise of asthenospheric mantle is augmented by heat from related igneous intrusions, thereby raising the temperature to $>1100^{\circ} \mathrm{C}$, as occurred at Mt. RiiserLarsen.

In summary, the thermal evolution of Mt. RiiserLarsen in the north of the Amundsen Bay area is presumed to have been as follows: (1) the intrusion of A-type granites at $2.6-2.5 \mathrm{Ga}$, (2) protracted HT conditions $>800^{\circ} \mathrm{C}$ at midcrustal levels during the period $\sim 2.51-2.48 \mathrm{Ga},(3)$ a short period (a few million years) of peak UHT conditions $>900^{\circ} \mathrm{C}$ just before $\sim 2.48-2.47 \mathrm{Ga},(4)$ relatively rapid cooling $\left(10^{\circ}-\right.$ $60^{\circ} \mathrm{C} / \mathrm{m}$.yr.) at $\sim 2.48-2.47 \mathrm{Ga}$, and then (5) very slow cooling $\left(\leq 4^{\circ} \mathrm{C} / \mathrm{m}\right.$.yr.) at midcrustal levels to the stable steady state geotherm until $\sim 2.38 \mathrm{Ga}$. This history requires a tectonic model for Mt. Riiser-Larsen involving heat input from both the uprise of asthenospheric mantle and igneous intrusions.

\section{A C K N O W L E D G M E N T S}

We express our heartfelt thanks to H. Ishizuka, M. Ishikawa, and T. Hokada for their valuable advice, support in the fieldwork, and stimulating discus- 
sions. We are grateful to K. Misawa and T. Hamamoto for stimulating discussions about the isotope analyses. Thanks are also due to H. Miura, M. Takada, and D. P. Zwartz for their help during the fieldwork. We would like to record our hearty thanks to all the members of Japanese Antarctic Research Expedition 38 and the crew of icebreaker Shirase for their cooperation during the fieldwork. The National Institute of Polar Research (NIPR) is thanked for the valuable support of our study. We thank J. Mya and S. Paxton for their expert mineral separations and the staff of the Australian National
University Electron Microscopy Unit and T. Hokada of the NIPR in Japan for their assistance with SEM imaging. We are grateful to R. Mazumder for his suggestions. The manuscript has benefited greatly from detailed constructive reviews by E. Essene and S. L. Harley. The Japan Society for the Promotion of Science (JSPS) is gratefully acknowledged for financial support to S. Suzuki while at the Graduate University for Advanced Studies. Parts of this study were supported by the Grant-inAid for Scientific Research provided by JSPS to M. Arima (13373005).

\section{R E F E R E N C E S C I T E D}

Annen, C., and Sparks, R. S. J. 2002. Effects of repetitive emplacement of basaltic intrusions on thermal evolution and melt generation in the crust. Earth Planet. Sci. Lett. 203:937-955.

Arnold, J.; Jacoby, W. R.; Schmeling, H.; and Schott, B. 2001. Continental collision and the dynamic and thermal evolution of the Variscan orogenic crustal rootnumerical models. J. Geodyn. 31:273-291.

Asami, M.; Suzuki, K.; and Grew, E. S. 2002. Chemical Th-U-total $\mathrm{Pb}$ dating by electron microprobe analysis of monazite, xenotime and zircon from the Archean Napier Complex, East Antarctica: evidence for ultrahigh-temperature metamorphism at 2400 Ma. Precambrian Res. 114:249-275.

Black, L. P.; Fitzgerald, J. D.; and Harley, S. L. 1984. Pb isotopic composition, colour, and microstructure of monazites from a polymetamorphic rock in Antarctica. Contrib. Mineral. Petrol. 85:141-148.

Black, L. P., and James, P. R. 1983. Geological history of the Napier Complex of Enderby Land. In Oliver, R. L.; James, P. R.; and Jago, J. B., eds. Antarctic earth science. Canberra, Australian Academy of Science, p. 11-15.

Black, L. P.; James, P. R.; and Harley, S. L. 1983a. Geochronology and geological evolution of metamorphic rocks in the Field Islands area, East Antarctica. J. Metamorph. Geol. 1:277-303.

- 1983b. The geochronology, structure and metamorphism of early Archaean rocks at Fyfe Hills, Enderby Land, Antarctica. Precambrian Res. 21:197-222.

Black, L. P.; Sheraton, J. W.; and James, P. R. 1986a. Late Archaean granites of the Napier Complex, Enderby Land, Antarctica: a comparison of Rb-Sr, Sm-Nd and $\mathrm{U}-\mathrm{Pb}$ isotopic systematics in a complex terrain. Precambrian Res. 32:343-368.

Black, L. P.; Williams, I. S.; and Compston, W. $1986 b$. Four zircon ages from one rock: the history of a 3930Ma-old granulite from Mount Sones, Enderby Land, Antarctica. Contrib. Mineral. Petrol. 94:427-437.

Burton, K. W.; Kohn, M. J.; Cohen, A. S.; and O'Nions, R. K. 1995. The relative diffusion of $\mathrm{Pb}, \mathrm{Nd}, \mathrm{Sr}$ and $\mathrm{O}$ in garnet. Earth Planet. Sci. Lett. 133:199-211.

Carson, C. J.; Ague, J. J.; and Coath, C. D. 2002. U-Pb geochronology from Tonagh Island, East Antarctica: implications for the timing of ultra-high temperature metamorphism of the Napier Complex. Precambrian Res. 116:237-263.

Cherniak, D. J., and Watson, E. B. 2001. Pb diffusion in zircon. Chem. Geol. 172:5-24.

Cherniak, D. J.; Watson, E. B.; Grove, M.; and Harrison, T. M. 2004. Pb diffusion in monazite: a combined RBS/ SIMS study. Geochim. Cosmochim. Acta 68:829-840.

Compston, W., and Williams, I. S. 1982. Protolith ages from inherited zircon cores measured by a high massresolution ion microprobe. Abstract, 5 th international symposium on geochronology, cosmochronology and isotope geology. Nikko, Japan, p. 63-64.

Crowe, W. A.; Osanai, Y.; Toyoshima, T.; and Owada, M. 2002. SHRIMP geochronology of a mylonite zone on Tonagh Island: characterisation of the last high-grade tectonothermal event in the Napier Complex, East Antarctica. Polar Geosci. 15:17-36.

Cumming, G. L., and Richards, J. R. 1975. Ore lead isotope ratios in a continuously changing earth. Earth Planet. Sci. Lett. 28:155-171.

Dallwitz, W. B. 1968. Coexisting sapphirine and quartz in granulite from Enderby Land, Antarctica. Nature 219:476-477.

Dodson, M. H. 1973. Closure temperature in cooling geochronological and petrological systems. Contrib. Mineral. Petrol. 40:259-274.

Ellis, D. J. 1980. Osumilite-sapphirine-quartz granulites from Enderby Land, Antarctica: $P-T$ conditions of metamorphism, implications for garnet-cordierite equilibria and the evolution of the deep crust. Contrib. Mineral. Petrol. 74:201-210.

- 1987. Origin and evolution of granulites in normal and thickened crusts. Geology 15:167-170.

Ganguly, J., and Tirone, M. 1999. Diffusion closure temperature and age of a mineral with arbitrary extent of diffusion: theoretical formulation and applications. Earth Planet. Sci. Lett. 170:131-140.

Ganguly, J.; Tirone, M.; and Hervig, R. L. 1998. Diffusion kinetics of samarium and neodymium in garnet, and a method for determining cooling rates of rocks. Science 281:805-807. 
Grew, E. S. 1980. Sapphirine + quartz association from Archean rocks in Enderby Land, Antarctica. Am. Mineral. 65:821-836.

1982. Osumilite in the sapphirine-quartz terrane of Enderby Land, Antarctica: implications for osumilite petrogenesis in the granulite facies. Am. Mineral. 67:762-787.

1998. Boron and beryllium minerals in granulitefacies pegmatites and implications of beryllium pegmatites for the origin and evolution of the Archean Napier Complex of East Antarctica. Mem. Natl. Inst. Polar Res. Spec. Issue 53:74-92.

Grew, E. S., and Manton, W. I. 1979. Archean rocks in Antarctica: 2.5-billion-year uranium-lead ages of pegmatites in Enderby Land. Science 206:443-445.

Harley, S. L. 1985. Garnet-orthopyroxene bearing granulites from Enderby Land, Antarctica: metamorphic pressure-temperature-time evolution of the Archaean Napier Complex. J. Petrol. 26:819-856.

. 1987. A pyroxene-bearing meta-ironstone and other pyroxene-granulites from Tonagh Island, Enderby Land, Antarctica: further evidence for very high temperature $\left(>980^{\circ} \mathrm{C}\right)$ Archaean regional metamorphism in the Napier Complex. J. Metamorph. Geol. 5:341-356.

1989. The origins of granulites: a metamorphic perspective. Geol. Mag. 126:215-247.

. 1998. On the occurrence and characterization of ultrahigh-temperature crustal metamorphism. In Treloar, P. J., and O'Brien, P. J., eds. What drives metamorphism and metamorphic reactions? Geol. Soc. Lond. Spec. Publ. 138:81-107.

. 2003. Archean-Cambrian crustal development of East Antarctica: metamorphic characteristics and tectonic implications. In Yoshida, M.; Windley, B. F.; and Dasgupta, S., eds. Proterozoic East Gondwana: supercontinent assembly and breakup. Geol. Soc. Lond. Spec. Publ. 206:203-230.

- 2004. Extending our understanding of ultrahigh temperature crustal metamorphism. J. Mineral. Petrol. Sci. 99:140-158.

Harley, S. L., and Black, L. P. 1987. The Archaean geological evolution of Enderby Land, Antarctica. In Park, R. G., and Tarney, J., eds. Evolution of the Lewisian and comparable Precambrian high-grade terrains. Geol. Soc. Spec. Publ. 27:285-296.

- 1997. A revised Archaean chronology for the Napier Complex, Enderby Land, from SHRIMP ionmicroprobe studies. Antarct. Sci. 9:74-91.

Harley, S. L., and Hensen, B. J. 1990. Archaean and Proterozoic high-grade terranes of East Antarctica (40$80^{\circ} \mathrm{E}$ ): a case study of diversity in granulite facies metamorphism. In Ashworth, J. R., and Brown, M., eds. High-temperature metamorphism and crustal anatexis. London, Mineralogical Society of Great Britain, Unwin Hyman, p. 320-370.

Harley, S. L.; Kenny, P. D.; Snape, I.; and Black L. P. 2001. Zircon chemistry and the definition of events in Archaean granulite terrains. In Cassidy, K. F.; Dunphy, J. M.; and Van Kranendonk, M. J., eds. 4th Int. Ar- chaean Symp. Canberra, Geosci. Australia, p. 511513.

Harley, S. L., and Motoyoshi, Y. 2000. Alumina-zoning in orthopyroxene in a sapphirine quartzite: evidence for $>1120^{\circ} \mathrm{C}$ ultrahigh temperature metamorphism in the Napier Complex, Enderby Land, Antarctica. Contrib. Mineral. Petrol. 138:293-307.

Hensen, B. J., and Motoyoshi, Y. 1992. Osumilite-producing reactions in high temperature granulites from the Napier Complex, East Antarctica: tectonic implications. ed. In Yoshida, Y.; Kaminuma, K.; and Shiraishi, K., eds. Recent progress in Antarctic earth science. Tokyo, Terra Scientific, p. 87-92.

Hokada, T. 2001. Feldspar thermometry in ultrahightemperature metamorphic rocks: evidence of crustal metamorphism attaining $\sim 1100^{\circ} \mathrm{C}$ in the Archean Napier Complex, East Antarctica. Am. Mineral. 86:932938.

Hokada, T., and Harley, S. L. 2004. Zircon growth in UHT leucosome: constraints from zircon-garnet rare earth elements (REE) relations in Napier Complex, East Antarctica. J. Mineral. Petrol. Sci. 99:180-190.

Hokada, T.; Misawa, K.; Shiraishi, K.; and Suzuki, S. 2003. Mid to Late Archaean (3.3-2.5 Ga) tonalitic crustal formation and high-grade metamorphism at Mt. Riiser-Larsen, Napier Complex, East Antarctica. Precambrian Res. 127:215-228.

Hokada, T.; Misawa, K.; Yokoyama, K.; Shiraishi, K.; and Yamaguchi, A. 2004. SHRIMP and electron microprobe chronology of UHT metamorphism in the Napier Complex, East Antarctica: implications for zircon growth at $>1,000^{\circ} \mathrm{C}$. Contrib. Mineral. Petrol. 147:120.

Hollis, J., and Harley, S. L. 2002. New evidence for the peak temperatures and the near-peak pressuretemperature evolution of the Napier Complex. In Gamble, J. A.; Skinner, D. N. B.; Henrys, S.; and Lynch, R., eds. Antarctica at the close of a millennium. J. R. Soc. N. Z. 35:19-29.

Ishikawa, M.; Hokada, T.; Ishizuka, H.; Miura, H.; Suzuki, S.; Takada, M.; and Zwartz, D. P. 2000. Explanatory text of geological map of Mount Riiser-Larsen, Enderby Land, Antarctica. Antarctic geological map series, sheet 37. Tokyo, National Institute of Polar Research, $23 \mathrm{p}$.

Ishizuka, H.; Ishikawa, M.; Hokada, T.; and Suzuki, S. 1998. Geology of the Mt. Riiser-Larsen area of the Napier Complex, Enderby Land, East Antarctica. Polar Geosci. 11:154-171.

Ishizuka, H.; Suzuki, S.; and Nakamura, A. 2002. Peak temperatures of ultra-high temperature metamorphism of the Napier Complex, Enderby Land, East Antarctica, as deduced from porphyroclastic pyroxenes of meta-ultramafic rocks. Polar Geosci. 15:1-16.

James, P. R., and Black, L. P. 1981. A review of the structural evolution and geochronology of the Archaean Napier Complex of Enderby Land, Australian Antarctic Territory. Geol. Soc. Aust. Spec. Publ. 7:71-83.

Kagami, H.; Iwata, M.; Sudo, H.; and Honma, H. 1987. $\mathrm{Sr}$ and $\mathrm{Nd}$ Isotopic Compositions and $\mathrm{Rb}, \mathrm{Sr}, \mathrm{Sm}$ and 
Nd concentrations of standard samples. Okayama University, Misasa, Japan, Institute for Study of the Earth's Interior, Tech. Rep. B4:1-16.

Kagami, H.; Okano, O.; Sudo, H.; and Honma, H. 1982. Isotopic analysis of $\mathrm{Rb}$ and $\mathrm{Sr}$ using a full automatic thermal ionization mass spectrometer. Papers of the Institute of Thermal Spring Research, Okayama University 52:51-70 (in Japanese with English abstract).

Kawano, Y. 1994. Calculation program for isochron ages of $\mathrm{Rb}-\mathrm{Sr}$ and $\mathrm{Sm}-\mathrm{Nd}$ systems using personal computer. Geoinformatics 5:13-19 (in Japanese with English abstract).

Kelly, N. M., and Harley, S. L. 2005. An integrated microtextural and chemical approach to zircon geochronology: refining the Archaean history of the Napier Complex, east Antarctica. Contrib. Mineral. Petrol. 149:57-84.

Krogh, T. E. 1973. A low-contamination method for hydrothermal decomposition of zircon and extraction of $\mathrm{U}$ and $\mathrm{Pb}$ for isotopic age determinations. Geochim. Cosmochim. Acta 37:485-494.

Lee, J. K. W.; Williams, I. S.; and Ellis, D. J. 1997. Pb, U and Th diffusion in natural zircon. Nature 390:159162.

Lugmair, G. W., and Marti, K. 1978. Lunar initial ${ }^{143} \mathrm{Nd} /$ ${ }^{144} \mathrm{Nd}$ : differential evolution of the lunar crust and mantle. Earth Planet. Sci. Lett. 39:349-357.

McCulloch, M. T., and Black, L. P. 1984. Sm-Nd isotopic systematics of Enderby Land granulites and evidence for the redistribution of $\mathrm{Sm}$ and $\mathrm{Nd}$ during metamorphism. Earth Planet. Sci. Lett. 71:46-58.

Mezger, K.; Essene, E. J.; and Halliday, A. N. 1992. Closure temperature of the Sm-Nd system in metamorphic garnets. Earth Planet. Sci. Lett. 113:397-409.

Möller, A; Post, N. J.; and Hensen, B. J. 2002. Crustal residence history and garnet $\mathrm{Sm}-\mathrm{Nd}$ ages of high-grade metamorphic rocks from the Windmill Islands area, East Antarctica. Int. J. Earth Sci. Geol. Rundsch. 91: 993-1004.

Motoyoshi, Y., and Hensen, B. J. 1989. Sapphirine-quartzorthopyroxene symplectites after cordierite in the Archaean Napier Complex, Antarctica: evidence for a counterclockwise P-T path? Eur. J. Mineral. 1:467471.

Motoyoshi, Y., and Matsueda, H. 1984. Archean granulites from Mt. Riiser-Larsen in Enderby Land, East Antarctica. Mem. Natl. Inst. Polar Res. Spec. Issue 33: 103-125.

Owada, M.; Osanai, Y.; and Kagami, H. 1994. Isotopic equilibration age of Sm-Nd whole-rock system in the Napier Complex (Tonagh Island), East Antarctica. Proc. Natl. Inst. Polar Res. Symp. Antarct. Geosci. 7, p. $122-132$.

Sandiford, M. 1985. The metamorphic evolution of granulites at Fyfe Hills; implications for Archaean crustal thickness in Enderby Land, Antarctica. J. Metamorph. Geol. 3:155-178.

Sandiford, M., and Powell, R. 1986. Deep crustal metamorphism during continental extension: modern and ancient examples. Earth Planet. Sci. Lett. 79:151-158.
Sandiford, M., and Wilson, C. J. L. 1986. The origin of Archaean gneisses in the Fyfe Hills Region, Enderby Land; field occurrence, petrography and geochemistry. Precambrian Res. 31:37-68.

Scherer, E. E.; Cameron, K. L.; and Blichert-Toft, J. 2000. Lu-Hf garnet geochronology: closure temperature relative to the Sm-Nd system and the effects of trace mineral inclusions. Geochim. Cosmochim. Acta 64: 3413-3432.

Sheraton, J. W., and Black, L. P. 1981. Geochemistry and geochronology of Proterozoic tholeiite dykes of East Antarctica: evidence for mantle metasomatism. Contrib. Mineral. Petrol. 78:305-317.

- 1983. Geochemistry of Precambrian gneisses: relevance for the evolution of the East Antarctic Shield. Lithos 16:273-296.

Sheraton, J. W.; Offe, L. A.; Tingey, R. J.; and Ellis, D. J. 1980. Enderby Land, Antarctica: an unusual Precambrian high-grade metamorphic terrain. J. Geol. Soc. Aust. 27:1-18.

Sheraton, J. W.; Tingey, R. J.; Black, L. P.; Offe, L. A.; and Ellis, D. J. 1987. Geology of Enderby Land and western Kemp Land, Antarctica. Aust. Bur. Min. Resour. Bull. 223, $51 \mathrm{p}$.

Shiraishi, K.; Ellis, D. J.; Fanning, C. M.; Hiroi, Y.; Kagami, H.; and Motoyoshi Y. 1997. Re-examination of the metamorphic and protolith ages of the Rayner Complex, Antarctica: evidence for the Cambrian (panAfrican) regional metamorphic event. In Ricci, C. A., ed. The Antarctic region: geological evolution and processes. Sienna, Italy, Terra Antarctica, p. 79-88.

Smith, H. A., and Giletti, B. J. 1997. Lead diffusion in monazite. Geochim. Cosmochim. Acta 61:1047-1055.

Sobotovich, E. V.; Kamenev, Y. N.; Komaristy, A. A.; and Rudnik, V. A. 1976. The oldest rocks of Antarctica (Enderby Land). Int. Geol. Rev. 18:371-388.

Steiger, R. H., and Jäger, E. 1977. Subcommission on geochronology: convention on the use of decay constants in geo- and cosmochronology. Earth Planet. Sci. Lett. 36:359-362.

Stern, R., and Sanborn, N. 1998. Monazite U-Pb and Th$\mathrm{Pb}$ geochronology by high-resolution secondary ion mass spectrometry (SHRIMP). Radiogenic age and isotopic studies: report 11. Ottawa, Geol. Surv. Can. 1998-F, 18 p.

Suzuki, K., and Adachi, M. 1991. Precambrian provenance and Silurian metamorphism of the Tsubonosawa paragneiss in the South Kitakami terrane, Northeast Japan, revealed by the chemical Th-U-total $\mathrm{Pb}$ isochron ages of monazite, zircon and xenotime. Geochem. J. 25:357-376.

Suzuki, S.; Kagami, H.; and Ishizuka, H. 2001a. Geochemistry and intrusive ages of Proterozoic dyke swarms from Mt. Riiser-Larsen in the Napier complex, East Antarctica. Tokyo, Japan Earth and Planetary Science Joint Meeting, abstract.

Suzuki, S.; Kagami, H.; Ishizuka, H.; and Hokada, T. $2001 b$. Sm-Nd mineral isochron age of sapphirinequartz gneiss from the Mt. Riiser-Larsen area in the 
Napier Complex, East Antarctica. Polar Geosci. 14: 88-89.

Tainosho, Y.; Kagami, H.; Hamamoto, T.; and Takahashi Y. 1998. Sm-Nd and Rb-Sr whole-rock systems of metamorphic rocks from mount Pardoe in the Napier Complex, East Antarctica. Gondwana Res. Group Mem. 4:185-198.

Thöni, M. 2002. Sm-Nd isotope systematics in garnet form different lithologies (Eastern Alps): age results, and an evaluation of potential problems for garnet SmNd chronometry. Chem. Geol. 185:255-281.

Tsunogae, T.; Santosh, M.; Osanai, Y.; Owada, M.; Toyoshima, T.; and Hokada T. 2002. Very high-density carbonic fluid inclusions in sapphirine-bearing granulites from Tonagh Island in the Archean Napier Complex, East Antarctica: implications for $\mathrm{CO}_{2}$ infiltration during ultrahigh-temperature $\left(\mathrm{T}>1,100^{\circ} \mathrm{C}\right)$ metamorphism. Contrib. Mineral. Petrol. 143:279-299.

Westphal, M.; Schumacher, J. C.; and Boschert, S. 2003. High-temperature metamorphism and the role of magmatic heat sources at the Rogaland Anorthosite Complex in Southwestern Norway. J. Petrol. 44:11451162.

Whalen, J. B.; Currie, K. L.; and Chappell, B. W. 1987. Atype granites: geochemical characteristics, discrimination and petrogenesis. Contrib. Mineral. Petrol. 95: 407-419.
Williams, I. S. 1998. U-Th-Pb geochronology by ion microprobe. In McKibben, M. A.; Shanks, W. C., III; and Ridley, W. I., eds. Applications of microanalytical techniques to understanding mineralizing processes. Rev. Econ. Geol. 7, p. 1-35.

Williams, I. S.; Buick, I. S.; and Cartwright, I. 1996. An extended episode of early Mesoproterozoic metamorphic fluid flow in the Reynolds Range, central Australia. J. Metamorph. Geol. 14:29-47.

Williams, I. S.; Compston, W.; Black, L. P.; Ireland, T. R.; and Foster, J. J. 1984. Unsupported radiogenic $\mathrm{Pb}$ in zircon: a cause of anomalously high $\mathrm{Pb}-\mathrm{Pb}, \mathrm{U}-\mathrm{Pb}$ and Th-Pb ages. Contrib. Mineral. Petrol. 88:322-327.

Williams, I. S., and Hergt, J. M. 2000. U-Pb dating of Tasmanian dolerites: a cautionary tale of SHRIMP analysis of high-U zircon. In Woodhead, J. D.; Hergt, J. M.; and Noble, W. P., eds. New frontiers in isotope geoscience. Lorne, University of Melbourne, Abstr. Proc., p. 185-188.

York, D. 1966. Least-squares fitting of a straight line. Can. J. Phys. 44:1079-1086.

Zhou, B., and Hensen, B. J. 1995. Inherited Sm/Nd isotope components preserved in monazite inclusions within garnets in leucogneiss from East Antarctica and implications for closure temperature studies. Chem. Geol. 121:317-326. 